\title{
31- 'Lilith' figürü üzerinden mitoloji ve dinlerdeki kadın algısına feminist perspektiften bakış
}

\section{Selin Cansu YETER ${ }^{1}$ \\ Kemal ÖZCAN²}

\begin{abstract}
APA: Yeter, S. C.; Özcan, K. (2022). 'Lilith' figürü üzerinden mitoloji ve dinlerdeki kadın algısına feminist perspektiften bakıș. RumeliDE Dil ve Edebiyat Araştırmaları Dergisi, (26), 506-525. DOI: 10.29000/rumelide.1073969.
\end{abstract}

\section{$\ddot{\mathbf{O z}}$}

Erkeğin kadına tahakkümünü içeren ataerkil ideoloji, kendi lehine işleyecek şekilde tarihe yön veren güçlü bir etkiye sahiptir. Tarihsel süreç içinde yaşanan olaylara ve toplumlara yerleşen eril zihniyet mitolojik anlatılarda ve dinsel metinlerde de etkisini hissettirmektedir. Kadının ve erkeğin toplumsal yaşamdaki yerini belirlemede etkili olan dini-mitolojik anlatı ve öğretiler, kadınların bugünkü konumunu anlamada önemli ipuçlarını oluşturmaktadır. Yaratılıştan bu yana var olduğu düşünülen Lilith efsanesi, tarihsel süreçte toplumların kadına bakışını anlamada önemli bir figür olarak görülmektedir. Bu çalışmada; feminist perspektiften, kemikleşen ataerkil ideolojik sistemin mitolojide ve dinlerdeki kadın algısını nasıl etkilediğine değinilecektir. Bununla birlikte bir kadın arketipi olarak Lilith’in tarihsel süreçteki konumu üzerinden ataerkil toplumların kadına yönelik algisı incelenecektir.

Anahtar kelimeler: Ataerkil toplum yapısı, Feminizm, Lilith, kadın algısı

\section{A feminist perspective on perception of women in mythology and religions through the figure of 'Lilith'}

\begin{abstract}
The patriarchal ideology, which includes the domination of men over women, has a powerful influence that shapes history to work in its favor. The masculine mentality, which settled in the events and societies in the historical process, also makes its impact felt in mythological narratives and religious texts. The religious-mythological narratives and doctrines, which are effective in determining the place of women and men in social life, constitute important clues in understanding the present position of women. The legend of Lilith, which is thought to have existed since creation, is seen as an important figure in understanding the society's view of women in the historical process. In this study, it will be discussed from a feminist perspective how the rooted patriarchal ideological system affects the perception of women in mythology and religions. In addition, society's perception of women will be discussed through Lilith's position in the historical process as a woman archetype.
\end{abstract}

Keywords: Patriarchal social structure, Feminism, Lilith, perception of women

YL Öğrencisi, Ondokuz Mayıs Üniversitesi, Kadın ve Aile Araştırmaları ABD (Samsun, Türkiye), slnytro24@gmail.com, ORCID ID: 0000-0001-9176-4193 [Araștırma makalesi, Makale kayıt tarihi: 03.01.2022-kabul tarihi: 20.02.2022; DOI: $10.29000 /$ rumelide.1073969]

Dr. Öğr. Üyesi, Ondokuz Mayıs Üniversitesi, Samsun Meslek Yüksekokulu, Çocuk Bakımı ve Gençlik Hizmetleri Bölümü (Samsun, Türkiye), kozcan@omu.edu.tr, ORCID ID: 0000-0003-4675-218X

\section{Adres | Address}

RumeliDE Dil ve Edebiyat Araştırmaları Dergisi Osmanağa Mahallesi, Mürver Çiçeği Sokak, No:14/8 Kadıköy - İSTANBUL / TÜRKIYE 34714 e-posta: editor@rumelide.com tel: +90 5057958124, +90 2167730616 


\section{Giriş}

Mitler insanın varlığını, evreni ve hayatı ele alan, onların olağanüstü menşeini anlamak ve yorumlamak amacıyla ortaya çıan anlatılardır. Mitler inanılan ve kutsal kabul edilen değerler sistemi ve kozmik bilgilerin sembolik bir taktimidir. Tüm toplumlar kültürel geçmişleri, din ve inanışlarını yansıtan mitolojik anlatılara sahiptir. Din, bu kutsal gerçekleri ve kültürü nesillere aktarmada aracı konumdadır.

Mitolojide ve dinlerde yer alan 'yaratılış anlatıları' insanın kültür hayatına geçişinin ana unsurlarını yansıtmaktadır. Yaratılış anlatılarındaki kadın-erkek algısı toplum hayatına yön veren nitelikler içermektedir. Tarih boyunca kadının fonksiyonlarının neler olduğunu anlamak için, onun hayat içerisindeki görünümlerine bakmanın yanı sıra Tanrısal dünyaya yansıtılan tasavvurlarını incelemek gerekmektedir. Yaratılıştan bu yana mitolojik anlatılarda ve dinsel öğretilerde çeşitli formlarda varlı̆̆ını sürdüren Lilith figürü, tarihsel süreç içerisinde kadına bakışın nasıl şekillendiğini anlamada önemli bir arketip olarak görülmektedir.

Üç semavi dinin kutsal kitaplarında, Adem ve Havva yaratılan ilk insanlar olarak yer almıştır. Ancak bazı hikaye ve mitlerde Havva'dan önce ilk kadın olarak Lilith’in yaratıldığından bahsedilmiştir. Lilith'e dair ulaşılabilen en eski izler Sümerlerin Gılgamış Destanı'nda; sonrasında ise Yahudi kültürüne dayanan Ben Sira Alfabesinde görülmüsstür. Ben Sira Alfabesinde Lilith, Âdem ile eşit yaratıldığını savunmuş ve bağımsızlığı uğruna cinsel ilişki sırasında Âdem'in altına yatmayı reddederek cennetten ayrılmıştır. Sonrasında ise insanlara musallat olan dişi bir şeytana dönüşmüştür. Lilith ölüm ve kaos getiren, itaatsizlikle ilişkilendirilen bir kötülük simgesi haline gelmiştir. Dünyaya gelen ilk kadın olduğu düşünülen Lilith'in böylesi olumsuz niteliklerle tanımlanması kadına dair var olan negatif algının geçmişten günümüze gelen bir göstergesidir. Kadınlarla kötülük arasındaki bağ kutsal metinlerde özellikle de Yahudi kutsal metinlerinde yılan-şeytan-kadın (Lilith) bileşimi bir figür olarak daha da belirginleştirilmiştir. Günümüzde ise feministler, kadına ilişkin oluşan bu algıyı sorgulamakta ve diğer tanımlamaların aksine Lilith'i, erkek egemen otoriteye karşı çıkan ilk cesur kadın olarak görmektedir.

\section{Mitoloji ve dinlerde kadına bakış}

Toplumlardaki ortak bilincin oluşmasına katkı sağlayan mitler, köklü bir geçmişe sahip olup ortaya çıktıkları toplumların kutsal gelenekleri, kültürel değer yargıları hakkında bilgi verir (Nar, 2014, s. 56). Mitler geçmişle bugün arasında bağ kurarak ilkel ve geleneksel toplumlardan bu yana insanların düşünce ve davranışlarını yönlendirir (Seyidoğlu, 2017, s. 10-11).

Mitler, evrenin yaratılışına dair kutsal ve gerçek hikâyeleri içerir. Evreni anlama, kutsal olanla bağlantı kurma isteği kadının ve erkeğin toplum içindeki konumunu çeşitli yönlerde etkilemiştir (Akmaz, 2019, s. 111-114). İlk mitolojik anlatılarda: "kutsallığın erkek olduğu kadar dişi biçimlerde de temsil edildiği ve her ikisinin ad ve biçimin ötesinde bir özün bölünmüş tezahürü” (Kef, 2018, s. 25) olarak ortaya çıkmıştır. Kutsalın cinsiyeti zamanla gücü elinde tutanlar tarafından belirlenme eğilimine gidilmiştir (Kurt, 2010, s. 48-56).

Mitler, toplumsal cinsiyet kabullerinde belirli sembollerle ortaya çıkarak kadınları ve erkekleri farklı şekillerde etkilemiştir (Kocabaş A., 2013, s. 21-22). Çoğunlukla Tanrı ve Tanrıça figürlerinin baş rolde olduğu mitler, insanî niteliklerden arınmış değildir. Tanrı ve Tanrıçalar hırs, bencillik, cinsellik, şehvet, aşk, aile ve eş gibi kavramlar yüklenmesi aracıllğıyla toplumların aynası gibidir (Gözen ve Adigüzel, 2017, s. 181). Bu sebeple toplumların kadın algısı ile Tanrıçalara atfedilen nitelikler arasında paralellik

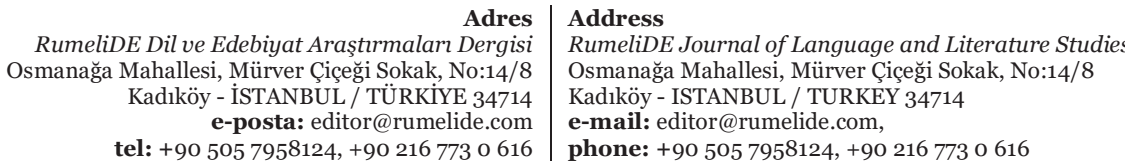


olduğu düşünülmektedir. Kutsalın dişil boyutu olarak görülen Tanrıça kültü, yaşanılan döneme ve toplumun kültürüne göre farklllaşarak mitolojik anlatılarda olumlu ya da olumsuz bir figür olarak anlatılmıştır. İlk çağlarda, "toprağın bitki vermesiyle kadının doğurması arasında bir bağ kurulması nedeniyle toprağın ruhunun kadın olduğuna inanılmıştır" (Kef, 2018, s. 28). Doğa ve toprak ile bağdaştırılan kadın, ana tanrıça ya da toprak ana gibi isimlerle özdeşleşen mitolojik ana kültüyle üstün ve değerli bir pozisyona koyulmuştur. Ancak zaman içinde ataerkil düzenin hüküm sürmeye başlaması ve erkek Tanrıların hegemonyası kadın Tanrıçalara olan ilgiyi azaltmıştır. Monoteist dinlerin de ortaya çıkmasıyla birlikte 'dişi-kutsallık' figürü dini-mitolojik alanda etkisini yitirmeye başlamıştır (Gültepe, 2017, s. 33-34). Eril zihniyet çerçevesinde ele alınan mitolojik anlatılarda kadın artık haz merkezinde yer alan, çıkar ilişkilerinin odağında, bedensel bir nesne veya entrikanın baş aktörü olarak şeytanlaştırılmış pozisyonlarda tanımlanmıştır (Yonar, 2019). Mitolojik anlatılarda kadının, güçlü kadın figürleriyle göksel dünyaya kadar taşındığı bir zamandan olumsuz ya da yetersiz bir kadın algısının yükselmeye başladığı bir zamana evrildiği görülmüştür. Bu değişim, toplumun yönetimindeki gücün el değiştirmesiyle açıklanabilir (Armstrong, 2005, s. 9-13).

Mitolojik anlatıların tekrarlanmasıyla toplumlar kendilerini yeniler. Periyodik olarak sunulan mitler, kültürlerin inşasında ve dinlerin tekrar yazımında başrolü üstlenmişlerdir (Kef, 2018, s. 23). Dinsel metinler ve öğretiler; mitolojik anlatılardan ve içinde bulunduğu kültürden etkilenen, tarihsel süreç içerisinde olgunlaşan ve sistemleşen bir kabuller silsilesidir. Dinsel metinler ve öğretiler tıpkı mitolojik anlatılar gibi doğrudan ya da dolaylı olarak yaşama yön veren etkiye sahiptir. Mitolojik anlatılar ve dini öğretiler, evreni ve insanın yaratılışını, birbirleriyle olan ilişkilerini açıklayan, düzenleyen ve yöneten kutsal bir kaynağa dayanan inanç ve ibadetlere dayanmaktadır. Bunun ötesinde toplumlara dair pek çok konuyu içinde barındıran dini-mitolojik anlatılar bir toplumun norm ve kurallarının kurgulanmasında, kadınlık ve erkeklik tanımlarında, cinsiyet kalıp yargılarının biçimlenmesinde önemli rol oynamaktadır (Yeniçeri, 2015, s. 14-16). Bu sebeple dini-mitolojik anlatılar, kadına yönelik bakışın şekillenmesinde de etkili olmuştur. Bu noktada, insanın kültür hayatına geçişinin ana unsurlarını yansıtan ve mitolojik imgelerden etkilenerek kutsal kitaplarda önemli bir konumda yer alan 'yaratılış anlatıları'ndaki kadın-erkek algısı toplum hayatına yön veren nitelikler içermektedir. Yaratılış anlatılarında kadına erkeğin aşă̆ısında ve onun bir parçası olma statüsü atfedilmiştir. Kadının erkek için yaratıldığı ve erkeğin kadından üstün olduğu düşüncesi yasak meyvenin işlendiği anlatılara da yansımıştır. Kökenleri çok daha eskiye dayanan bu anlatılar toplumsal hayatta kadınlara yönelik algıyı büyük ölçüde etkilemiştir.

Toplumsal yaşamın morfolojik faktörleri, dini-mitojik anlatılar kadın ve erkek arasındaki muhalefetin ve mücadelenin örneklerini yansıtma özelliğine sahiptir. Dini-mitolojik olarak erkeklere layık görülen birtakım kültürel ve Tanrısal kodlamalar anaerkil toplum düzeninin yaşandığı çă̆larda kadınlara ait olarak görülmüştür (Eliade, 1990, s. 143-144). Başlangıçta kadın ve erkeğin eşit denebilecek statüde bulunduğu düşünüldüğünde zamanla tarımın keşfiyle birlikte toplumsal yaşamın ürünü olarak oluşan toplumsal cinsiyet rolleri, işlevlerindeki değişimler ve erkeğin kadının doğurganlığı üzerindeki sosyal kontrolü kadın-erkek eşitsizliğinin başlangıcı olarak görülmüştür. Kendi soyundan geleni, kendine benzeyeni dünyaya getirmek için kadının bedenine, doğurganlığına ihtiyacı olduğunu ve kadının doğal üstünlüğünü fark eden erkek bu iktidarsızlı̆̆ını başka iktidarlar kurarak telafi etmek istemiştir. Ancak bu eşitsizlikten mutlak erkek egemenliğine geçiş ve erkek değerlerinin üstünlüğünün evrensel olarak kabulü başka mekanizmaların devreye girmesini gerektirmiştir (Tuğrul, 2010, s. 49-70). Bu noktada pek çok alanda mutlak egemenliğini kuran eril zihniyet, Tanrısal dünyayla kurulan bağda da bu gücünü kullanarak kadınları kötü ve kaçınılması gereken varlıklar olarak tanımlamıştır. Bu zihniyet çerçevesinde içselleştirilen kalıp yargılar yüzyllar boyunca sistemli ve kümülatif bir şekilde

Adres Address RumeliDE Dil ve Edebiyat Araştırmaları Dergisi
Osmanağa Mahallesi, Mürver Çiçeği Sokak, No:14/8 Kadıköy - İSTANBUL / TÜRKIYE 34714 tel: +90 5057958124, +90 2167730616

RumeliDE Journal of Language and Literature Studies

Osmanağa Mahallesi, Mürver Çiçeği Sokak, No:14/8

Kadıköy - ISTANBUL / TURKEY 34714

e-mail: editor@rumelide.com,

phone: +90 $5057958124,+902167730616$ 
sürdürülmüştür. Kadına yüklenen ikincil statü ve negatif algı günümüzde de derin bir şekilde toplumsal yaşamda etkisini hissettirmektedir.

\section{Feminizmin kadının konumuna, sorunlarına ve dine bakışı}

Feminizm köken olarak Latincede kadın ya da dişi anlamına gelen 'femina' kelimesinden türemiştir. Sonuna '-izm' eki alarak bir hareket ya da kuram olma özelliği kazanmıştır. 1789 Fransız Devrimiyle birlikte gelen özgürlük, hak, eşitlik kavramlarının sadece erkekler için değil kadınlar için de var olması gerektiği fikri feminizmin çıkış noktası olmuştur. 19. yüzyıl ve sonrasında ise feminizm, modern anlamda hız kazanmaya başlamıştır. Özellikle Yahudi toplumlarındaki ataerkil yapıda kadınlara sadece aile içindeki rolleri ve anneliği üzerinden pozitif değer verilmesi, sosyal, siyasi ve ekonomik alanlardan soyutlanmış konumda olmaları, erkek karşısındaki ikincil konumları, katı ve kadını aşağılayan dini geleneklerin olması onları özgürlük arayışına itmiş ve feminist hareketlerin öncülüğünü üstlenmişlerdir. İlk başlarda kadın hakları savunuculuğu fikri ile kavramlaşan feminizm, temelde eşitlik ve hak elde etme girişimi olarak görülse de feminist hareketler tarihsel dönüşümlerle çeşitli konuları içeren, farklı tanım ve bakış açlarıyla kendini yenileyen bir öğreti hâline gelmiştir. Bir ideoloji ve döngüsel süreç içeren, ulusal ve uluslararası boyutlarda ortaya çıkarak birçok toplumu etkileme özelliğine sahip olan feminizm, tek koldan ilerleyen bir yapıda değildir. Farklı dönemlerde farklı boyutlarda ve gruplarda ortaya çıan birçok feminist hareket bulunmaktadır. Her bir gruba dahil bireylerin kendi feminizm tanımları ve açıklamalarındaki görüş farklılıkları bu kavramın anlamının genişlemesine sebep olmuştur. Hem kullanımda hem de tanımlamadaki çeşitliliği feminizm kavramının bütünsel bir yaklaşımla ele alınmasını zorlaştırmıştır. Ancak farklı tanımlamalar içerse de feminizm 'kadın' etrafında şekillenmiştir. Feminizm'de kadın erkek arasında doğal ya da normal kabul edilen eşitsizlik ve cinsiyetçi rol dağılımı sorgulanmıştır. Kadının toplumdaki rolü ve statüsü, ezilmişliği ve sömürüsü, toplumsal cinsiyet ayrımcılı̆̆ı, kadını erkeğin karşısında ikincilleştiren ataerkil yapı ve tahakküm ilişkisi feministlerce geniş ölçüde tartışılan konular olduğu görülmüştür. Her feminizm hareketi kendi sorunları çerçevesinde hareket etse de genel feminizm anlayışından kopmamıştır. Bu bağlamda feminizm kadınların siyasi, sosyal, ekonomik, hukuki ve kültürel alanlarda yaşadıkları sorunlarını en aza indirgeyebilecek yollar arama çabasıyla yürütülen hareketler dizisidir (Şahin, 2013, s. 9-37).

Feminizmin üç dalga hâlinde yayıldığı görüşü hakimdir. Birinci dalga feminizm, çoğunlukla siyasi talepler yani oy elde etme hakkı etrafında ortaya çıkmıştır. Ayrıca kadınların erkek dünyasına -kamusal alana- katılma, eğitim ve eşit haklara sahip olma mücadelesi ele alınmıştır. İkinci dalga feminizmin başlangıç noktası 1960'l ve 1970'li yllar olarak kabul edilmiştir. Bu dalgada medeni ve kamusal hakların masaya yatırıldığı, evlilik, aile kurumunun ve kadınların özel, ev içi işlere hapsedilmişliğinin sorgulandığı görülmüştür. Kadın cinsinin farklılığı üzerinde durarak öteki olmanın ayrıcalı̆̆ı ve kadının doğurganlığı tartışılmıştır. Bu dönemde ataerkil ve kapitalist sistemden kurtulma çabası ağır basmıştır. Üçüncü dalga feminizmdeki feminist hareketlerin özel durum ve koşullar içerisinde daha özgür bir biçime dönüştüğü, daha bireysel kutuplaşmalara doğru gidildiği, kadın bakış açısının çeşitlilik gösterdiği bir dönemi içine aldığı görülmüş̧ür. Bu dönemde, cinsiyet ve cinsellik radikal boyutlarda geniş bir şekilde ele alınmıştır. Üçüncü dalgada farklı bölge ve ırklardaki kadınların sorunları, erkek egemenliğinin doğa ve kadın karşısındaki üstünlüğü ve sömürüsü, kadın ve erkek eşitliğinden ziyade insan eşitliği konularını ele alan farklı feminist hareketler ortaya çımıştır (Donovan, 2014, s. 319-405). Bu dönemler ele alındığında her dalga birbirini tamamlamış ve bir diğerinin gelişimini desteklemiştir. Her bir dalga bir önceki dalganın yanlışları veya eksikleri üzerine yoğunlaşarak kendi çapında kazanımlar sağlamıştır. Böylece kadın ve erkek arasındaki farklılıkları asgari düzeye indirmeye yönelik ciddi mücadeleler verilmiştir.

Adres

RumeliDE Dil ve Edebiyat Araştırmalar Dergisi Osmanağa Mahallesi, Mürver Çiçeği Sokak, No:14/8 Kadıköy - İSTANBUL / TÜRKIYE 34714 tel: $+905057958124,+902167730616$
Address

RumeliDE Journal of Language and Literature Studies

Osmanağa Mahallesi, Mürver Çiçeği Sokak, No:14/8

Kadıköy - ISTANBUL / TURKEY 34714

e-mail: editor@rumelide.com

phone: +90 $5057958124,+902167730616$ 
Feministler ataerkil yapının, erkek ve kadın arasındaki iktidar ilişkisinin yeniden üretilmesinde etkili olan tüm ideolojik ve kurumsal yapıların aleni ya da örtük bir şekilde örgütlenmesini desteklediğini ileri sürmüşlerdir (Akça ve Tönel, 2011, s. 15). Ataerkil zihniyet çerçevesinde oluşturulan sosyal yaşamdaki hiyerarşik yapının kutsallık katılarak meşrulaştırılması için dinin kullanıldı ̆̆ını iddia etmişlerdir. Bu doğrultuda: "Erkekler ve kadınlar arasındaki farklılıkları belirleyen din midir yoksa içinde yaşadıkları toplumun dini paradigmaları mıdır?” (Palabıyık, 2019, s. 81) sorusu çerçevesinde din, feministler tarafından sorgulanmaya başlanmıştır. Din kapsamındaki feminist hareketlerin iki boyutta gerçekleştiği söylenebilir. Bunlar; cinsiyetçi olduğunu düşündükleri kültürü ve dini tamamen reddedenler; dinin özünde eşitlikçi olduğu ve bu özü bozmadan kendi kültürlerine yeni değerler getirmeye çalışanlar olarak ele alınabilir. Son yıllarda pek çok dindar reformcu feminist, dinlerin doğru bir şekilde anlaşıldığı takdirde, kadınları aşağılamadığı ve eşitsizliği desteklemediğinin görüleceği düşüncesini savunmaktadır. Tek Tanrılı dinlerin ilk dönemlerinde kadınların esasında iyi konumlarda olduklarını ancak tarihsel süreç içinde toplumda geri planda kalışlarının asıl sebebinin ataerkil toplumların gelenekleri ve geleneksel din öğretileri olmasının yanı sıra bu gelenekler çerçevesinde kadınların sistematik olarak mağdur edildiklerini ifade etmektedirler (Çaha, 2010, s. 305-360; Ali, 2014, s. 13-50; Donovan, 2014, s. 69-127).

\section{'Lilith' figürü üzerinden toplumlardaki kadın algısı ve feminizm}

Feministler, kadınların toplumsal ezilmişliklerine ve erkek karşısındaki ikincil konumlarına tepki göstermektedirler. Feministler kadınların erkeklerle eşit şartlarda ve özgür bir yaşam sürmeleri için mücadele etmektedirler. Lilith, eril tahakkümden kurtulmak isteyen birçok feminist akımın ilham kaynağı ve sembolü olmuştur. Ataerkil ideolojinin şeytani bir varlık olarak sunduğu Lilith, feministler tarafından erkek egemen otoriteye boyun eğmeyi reddeden ilk kadın olarak görülmüştür. Özellikle Yahudi feministler Lilith’in hikâyesini kadın bakış açısıyla yeniden ele alarak onun cesaretine ve bağımsız karakterine odaklanmıştır. Lilith’in Ademle eşit koşullarda yaratılması onlar için olumlu bir temsil olmuştur (Yeniçeri vd., 2015, s. 1036).

Lilith miti, kadın kimliklerinin toplumsal inşasında tarih boyunca birçok söylemsel bağlamda yer almıştır. Dünya mitolojisinde pek çok kadın karakteri andıran ve onlarla benzeşen özellikleri bulunan bir figür olmuştur. Bu mit, ataerkil normlarla şekillenen toplumsal cinsiyet rollerini meşru kılma ve tahakküm ilişkisinin sürekliliğini sağlama amacıyla eril zihniyet tarafından erkek yanlılığıyla ele alınarak günümüze kadar belirli ritüellerle pekiştirilmiştir. Feministler, erkek ve kadının insan oluşları açısından aynılık gösterdiğini ancak kültürü elinde tutan eril gücün toplumsal koşullarda kadına atfettiği sembolik özelliklerle dişil olanı ikincil plana itecek değerler yüklendiğini belirtmişlerdir (Şahin, 2013, 326-335). Onlara göre eril ideoloji tarafından, tıpkı kadınlara yapıldığı gibi Lilith'e de negatif anlamlar yükleyerek güçlü ve olumlu yönleri bertaraf edilmeye çalışılmıştır. Toplumsal koşullardan bağımsız düşünülmeyen bu anlatılardan yola çıkarak yaratılan ilk kadın olduğu düşünülen Lilith’in konumu ile toplumların kadın algısı arasındaki bağ dikkat çekmektedir. Bu sebeple tarihsel ve dini gerçeklikler göz önünde tutularak Lilith’in kökenini, tarihsel serüvenini ve değişimini ele almak toplumların kadına yönelik bakışını anlamak açısından faydalı olacaktır.

Köken olarak Sümerce 'lîl' kelimesinden türeyen Lilith’e dair farklı dillerde yakın anlamlar içeren kelimeler yer almıştır. Şöyle ki; Babilce Lilîtu, Asurca Līlātu, İbranice Laylâ, Arapça Leylâ, Habeşçe Lelìt, Aramice Lèylā, Süryanice Leyla (Çınar, 2018, s. 366; Kılıç ve Eser, 2018, s. 34) gibi adlarla benzerlik gösterdiği görülmüştür. 'Lîl' kelimesi 'rüzgâr, ruh, nefes ve hava' anlamına geldiği gibi 'zehir ve salgın hastalık' anlamlarını da içermektedir. Bu anlamlar dâhilinde Lilith’in bir şekilde hava

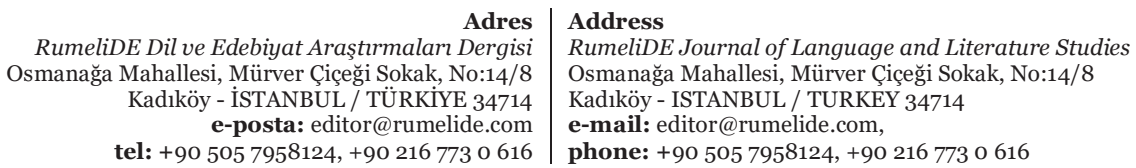


unsurlarıyla bağlantılı olduğu düşünülmektedir (Çınar, 2018, s. 363-367). Mezopotamya kültüründe havaya ait, rüzgârın yıkıcıllğıyla şehvetin birleştirildiğgi 'lilitu' isimli dişi (cin) varlığın ve 'Lîl' adlı bir Fırtına Tanrıçasının bu görüşü kuvvetlendirdiğini söylemek mümkündür (Altunay, 2014, s. 177). Kökeninde hava unsurlarıyla ilişkili olması Lilith'e ruhsal bir anlam kazandırmıştır. A. Çınar (2018) Thompson'dan (1903) alıntılayarak; Akadça, 'Tanrı' anlamına gelen 'ilu-alu/iltu' kelimelerinin de 'lil' ile aynı anlamda kullanıldığını belirtmiştir. Lil ve türevi (lilû, lilitu, lilî...) kelimelerin iyi ya da kötü ruhları temsil ettikleri ve Tanrısal olanla ilişkilendirilerek yüceltildikleri görülmüştür.

Birçok kültüre, dine ve zaman dilimine yayllan Lilith'in adına ilk olarak yaklaşık MÖ 2000 yll öncesine dayanan Sümerlerin yaratılış öyküsü Gılgamış Destanı'nda rastlanmıştır (Çınar, 2018, s. 365-366). Destana göre; Fırat ırmağının kenarına dikilmiş olan Huluppu Ağacı, güney rüzgarının etkisiyle kökünden koparak bu ırmak boyunca sürüklenirken o sırada ırmağın kenarından geçen Tanrıça İnanna ağacı görmüş ve onu alıp tapınağına getirerek kendi kutsal bahçesine dikmiştir. Bu ağaçla kendisine bir taht, kürsü ve yatak yapma isteği olan İnanna ağaca büyük bir özenle bakmıştır (Kramer, 1999, s. 71-72; Zingsem, 2007, s. 17-20). Ylllar sonra büyüyen ağacı kesmek istediğinde: “ (...) O zaman evcilleşmeyen bir yllan / yuvasını huluppu ağacının köklerine kurdu / Ağacın dallarında Anzu-kuş kuluçkaya yattı / Ve gövdesinde karanlık bakire Lilith evini inşa etti...” (Özbay, 2013, s. 45). Ağacı kesemeyeceğini anlayan İnanna büyük bir hüzünle Uruk kentinin Kralı Gılgamış’tan yardım istemiştir: "Gılgamış eğitilemeyen yllanı öldürdü. Anzu-Kuş yavrularıyla dağlara uçtu. Ve Lilith evini yıkarak vahşi, ıssız yerlere kaçtı" (Çınar, 2018, s. 365). Gılgamış ağacın gövdesinden İnanna'ya vermek için bir taht ve yatak oymuş, İnanna da ağacın köklerinden pukku ve tepesinden mikku yaparak cesaretinin bir ödülü olarak Gllgamış'a sunmuştur (Kramer, 1999, s. 72-73; Çı̆̆, 2015, s. 7).

Huluppu ağacı etrafinda geçen bu anlatıya ilişkin farklı yorumlamaların olduğu görülmüştür. Buna göre; Tanrıça İnanna'nın (İştar) kutsal evlilik teklifini, onun gücü altında ezilmemek ve ona boyun eğmemek için reddeden Gılgamış'ın aralarında küslük yaşanması sebebiyle Tanrıça'ya Huluppu ağacından bir taht yapmak istediği ve ağacı kesmek isterken Lilith ile karşılaştığı görülmüsstür. Ağacın gövdesinde Bakire Tanrıça Lilith’in evi, dallarında aslan-kartal görünümlü kuş, köklerinin altında yılanın yaşadığı belirtilmiştir (Gezgin, 2007, s. 72). Glgamış ağacı keserek Lilith’i özgürlüğüne kavuşturmuştur (Ramazanoğlu, 1944, s. 53). İki yorumdan yola çıkarak destanın orijinal metninde bulunan ki-sikillîl-lâ ifadesinin Lilith ile ilişkili olduğu görülmüştür. 'Kì Sümerce yer ya da bölge anlamında; 'sikil' temiz, taze veya bakir olarak çevrilmiştir. 'Ki-sikil'in ise, kutsal bölge veyahut tapınağa işaret eden 'el değmemiş/bakir yer' anlamına geldiği görülmüştür (Çınar, 2018, s. 366). 'Lîl-lấ' ifadesi ise, S. Kramer (1999) tarafindan Lilithle özdeşleştirilerek ‘dişi cin' olarak çevrilmiştir. Bu bilgiler dahilinde A. Çınar (2018) bu ifadeyi, "bakir bir kutsal alana çöreklenmiş dişi ruh" olarak yorumlamıştır. Kisikillîllâ ifadesine dair başka bir yorumda, 'kis ya da kıs' günümüzde kullanılan kız kelimesiyle benzerlik gösterdiği, ergenlik çă̆ına gelmemiş kadın anlamını içerdiği ve lil-la kelimesinin gökyüzü ve rüzgarı temsil ettiği belirtilmiştir. Bu anlamlara göre Kisikillillâ ifadesi "gökyüzünün bakir temiz saf kızı" olarak yorumlanmıştır (Url, 1). Bu anlatıda Lilith'e dair başka bir bilginin yer almadığı ve yorum farklılıkları olduğu görülmüştür. Anlatıda Lilith’in kötülük, uğursuzluk ya da şeytanla bağdaştıracak özellikler taşıdığına yönelik doğrudan bir atıf olmadığı dikkat çekmektedir.

Bu anlatının simgesel çözümlemesi yapıldığında Huluppu ağacı, kutsal görülen ve Tanrıyla olan iletişimde aracı konumda olan bir figürdür (Öztekin, 2008, s. 43). Aslan-kartal betimlemeleriyle de tasvir edilen An-Zû kuşu, kimi zaman hastalığa sebep olan bir cin kimi zaman da yer altı Tanrısı olarak betimlenmiştir. Kaderi tayin etme, güç ve bilgelik yönleriyle İmdigut kuşu bir diğer adıyla baykuşla

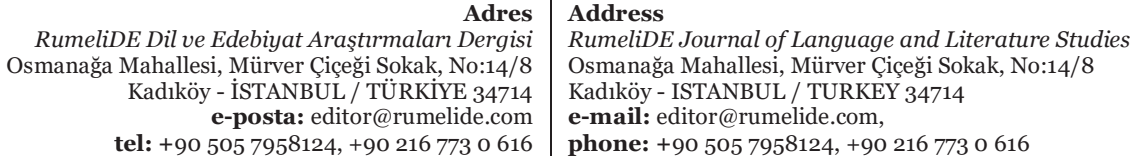


512 / RumeliDE Journal of Language and Literature Studies 2022.26 (February)

A feminist perspective on perception of women in mythology and religions through the figure of 'Lilith' / / S. C. Yeter; K. Özcan (pp. 506-525)

imgesel olarak örtüşmektedir (Hooke, 1993, s. 62-64; Zingsem, 2007, s. 215-221). Ana Tanriçayla özdeşleştirilen veya kutsal bir varlık olarak nitelendirilen Lilith yllanla birlikte imgeleştirilmiştir. Anlatıda Huluppu ağacı, kuş, yılan ve Lilith iç içe geçmiş mitolojik simgeler olarak görülmüştür. Birbirine kenetlenmiş olan bu imgeler, Tanrıça İnanna'nın hüküm sürdüğü anaerkil düzende kutsal kabul edilen ögelerdir. Gılgamış’ın dişil olanın kutsallığını yansıtan bu ögelere yönelik yıkıcı müdahalesi oldukça manidardır (Özbay, 2013, s. 46-47). Kutsal olanın eril olduğu düşüncesine hakim ataerkil anlayış için, dişil bir ilah olan İnanna'nın kutsallığını yansıtan bu ögelerle sağladığı güç bir tehdit olarak nitelendirilebilir.

Lilith, düalitenin sembolü ylanın özellikleri altında pek çok kez tasvir edilmiştir. Yılan, özünde doğumölüm, tarım-ekonomi gibi zıtlıkları içinde barındıran gizemli bir figürdür (Çınar, 2018, s. 378). Yılan imgesi:

"İyi ve kötü güçlerin mücadelesinde her zaman önemli bir rol üstlenmiștir. Fakat yılan bu mücadelede çoğunlukla dişil gücü temsil etmiş ve iktidarı simgeleyen eril güce yenik düşmüştür. Her ne kadar eril güç tarafindan alt edilse de yine eril gücün soyunu sürdüren de o olmuştur. Yaratılış mitlerinde doğurganlığı, üremeyi sağlamıștır yani neslin devamını getirmiștir. Fakat bu özelliklerine rağmen yarattıklarına da düşman olup onları yok etmek isteyen de bir yönü vardır. Dişil gücü temsil etmesinin yanı sıra görünüşü bir fallusu andırmaktadır ve eril tarafı ön plana çıkmaktadır. Aynı zamanda yılan firavunların taçlarında yer alır ve takip edilmesi gereken bir lider gibidir. Çünkü onda bilinmeyen sırlar ve sonsuzluk vardır. Bu yönleriyle de yllan bir bilge konumundadır ve herkesi yönlendirir. Şeytan yılan olarak anılan yılan ise, kötü özelliklerini hilebaz figürü üzerinden gösterir. Yılan, iyileştirici-tedavi edici özellikleriyle de çoğunlukla yeniden doğuşu ve annenin iyi eden olumlu özelliklerini ortaya koyar" (Sivri ve Akbaba, 2018, s. 63).

Yllanla bağdaştırılan Lilith’in dişil kozmik gücü temsil ettiği söylenebilir. F. Bayat’a (2012) göre, tek Tanrılı dinlerde kötü ruhların ve kötü gücün simgesi olarak tasvir edilen yılan eski toplumlarda olumlu niteliklere sahip simgesel bir varlık olarak görülmüştür. Eski kültürlerde kadınların Tanrıçalık, annelik ve doğurganlık vasıfları yılan -güç ve egemenlik- ve gizemli bilgelikle ilişkilendirilmiştir. Ancak kadın ve yılan imgesinin birbirine kenetlenmiş formları zaman içerisinde kötülükle bağdaştırılarak şeytani formlarda sunulmaya başlanmıştır. Yılan-kadın imgesinin bu dönüşümünün toplumsal koşullardaki değişimlerle yakından ilişkili olduğu söylenebilir.

İlk çağlarda -anaerkil düzenin hakim olduğu düşünülen- kadın, erkeğin ötekisi olmaktan ziyade kendi egemen kültürünü ve mitosunu oluşturabilecek güce sahip olmuştur. Tarım öncesi ya da avcı toplayıcı yaşam biçiminin yaşandığı bu dönem, kadın-erkek eşitsizliğinin minimum düzeyde olduğu veya hiç olmadığı bir süreci içermiştir. Aynı zamanda insanın doğaya hükümetmekten ziyade onunla uyum içinde yaşam sürdüğ̈̈ bir dönem olmuştur. Tarım öncesi dönemde kadının daha çok toplayıcılık görevini üstlenmesi, bereketin ve üreticiliğin simgesi olan toprakla içe içe olmasını sağlamıştır. Kadının doğayla olan ilişkisi onu önemli ve üstün kılmıştır. Toprağın bereketi kadının doğurganlığıyla özdeşleştirilmiştir. 'Bereket ya da Ana Tanrıça' kültü ve eski kültürlere dayanan Şamanizm'deki ritüeller, kadın şamanların iyileştirici ve kutsayıcı gücü bu durumun önemli simgelerindendir (Drury, 1989, s. 154-155). Toplumsal cinsiyet açısından düşünüldüğünde toprakla özdeşleştirilen, yaşamla ölümü elinde tutan ve doğa güçlerini yöneten kadının yaşam içinde değerli bir konumda olduğu söylenebilir (Depe, 2010, s. 467). Ancak tarımın keşfiyle toprağı işleme ve elde tutma çabası olarak belirtilen mülkiyet anlayışı dengeleri değiştirmiştir. Fiziksel olarak daha güçlü olduğu için tarlayı sürmeyi kendine görev edinen erkek, kadını bu alanın dışında tutmuştur. Artık kadın doğadaki ya da ev dışındaki aktif görevinden soyutlanmış ve ev içi özel alanda konumlandırılmıştır. Erkeği kamusal alana kadını özel alana layı gören bu yeni düzenle birlikte toplumsal cinsiyet rol ayrımının ve eşitsizliğinin temelleri atılmıştır. Erkeği öne çıkaran bu yaşam biçimi, kadının erkek karşısındaki ikincil konumunun da

\footnotetext{
Adres $\mid$ Address

RumeliDE Dil ve Edebiyat Araştırmaları Dergisi Osmanağa Mahallesi, Mürver Çiçeği Sokak, No:14/8 Kadıköy - ISTANBUL / TURKIYE 34714 e-posta: editor@rumelide.com tel: +90 $5057958124,+902167730616$

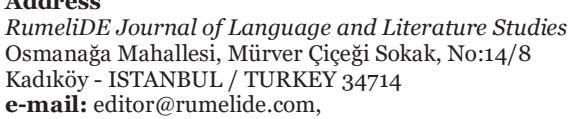


kültürel başlangıcı olmuştur. Erkek ve kadın arasındaki eşitsizlik esasında insan ve doğa arasındaki eşitsizliğin bir görünümüdür. İnsanın doğayı istismarıyla başlayan serüven, tarıma ve yerleşik yaşama geçişle elde edilen kültürel kazanımlarla pekiştirilmiştir. İlk eşitsizliğin türevi olan bir diğer eşitsizlik erkek ve kadın arasında gerçekleşmiştir. Erkek sadece tarlada -doğada- değil kadın üzerinde de hakimiyet kurmaya başlamıştır. İlerleyen süreçte toplumlar tarafından içselleştirilen ve kurumsallaşan eril güç, kadını hemen her alanda denetleme, her bakımdan aşağılama ve kendine bağımlı kılma anlayışını sürdürmüştür (Atay, 2004, s. 15-46).

Ataerkil toplumlarda gökyüzünü ve kutsallığı temsil eden Eril Tanrı'nın özellikleri arasında olan güç ve bereket, anaerkil düzende toprak ve doğayla özdeşleştirilen dişil ilahilerin doğurganlık ve koruyuculuk vasıflarını sembolize etmektedir. Dişil Bereket Tanrıçasından Eril Gök Tanrıya geçiş toprağa tapan insandan toprağı kendine mülk edinmeye çalışan insana dönüşümle olmuştur: "kadın artık yaşamın kaynağı, cömert ve bereketli toprak değil, erkeğin yarattığı canı içinde tutup büyüten taşıyıcıdan ibarettir" (Berktay, 2000, s. 59). Özne konumundaki 'kadın ve toprak' yerini 'erkek ve tohuma' bırakmıştır. Kadının doğurganlığı üzerinde etkisi olduğunu fark eden erkek, tıpkı tohumun topraktan çıktı̆̆ı gibi kendisinin de kadın bedeninden çıkarak hayat bulduğu gerçeğini göz ardı ederek kendini üstün görmüştür: "Tohum olmazsa toprağın ürün veremeyeceği, erkek olmazsa kadının var olamayacağı, saban tarımının yerleşik geçim biçimi olduğu toplumların yaratılış mitolojilerine damgasını vurur" (Atay, 2004, s. 16). Kadını simgeleyen pek çok unsur da kutsallıkla değil aşağı ve bayağı olmakla ilişkilendirilmiştir. Kadının cinselliğinin kutsallığı ve cinsel yaşam, yaratılışın bilinmezliğiyle iç içe geçmiştir. Kadın bir yandan kendinden olmayanı doğurma özelliğiyle eril gücü beslemekte bir yandan da ölüm ve yaşam döngüsünü sürdürmektedir (Campbell, 1995, s. 384-385). Yılan imgesi de kadına atfedilen bu özellikleri bünyesinde barındırmaktadır: "Yılan toprakta yaşar ve toprağın derin gövdesinden çıkan yaşam suyunun tecessümüdür. Yılan, hayat-madde varoluş alanındaki yaşam gücüdür. Deri değiştirmesiyle kendi kendini yeniler" (Tokyürek, 2016, s. 304). Yılan ve kadının, ana rahmini andıran karanlık yeraltıyla ilişkisi de bu noktada önemlidir (Sivri ve Akbaba, 2018, s. 58). Kadın rahminin ve yllanın birlikteliği belirsizliği ve gizemi temsil eden güçlü simgelerdir. Bakire-kadın mitosunda ortaya çıkan güç de buradan gelmektedir. Bakire mitosu, kadının doğal egemenliğini să̆layan nitelikleri kapsamaktadır (Işsk, 2018, s. 191). Öte yandan ataerkil toplumlarda medeniyet, akıl, kültür ve kutsallık erkeğe atfedilen özellikler olmuştur. Kadın ise bedenin, duyguların, rasyonel olmayanın, bilinmeyenin ve yokluğun temsilcisidir (Berktay, 2010, s. 23-33). Kadının doğurganlı̆̆ını yansıtan gizemli gücü aklın ötesinde bir üstünlüktedir. Dünyanın gizemliliği gibi kadın bedenindeki bu gizem de erkek için kadın korkusunu ve kadın uyarısını da beraberinde getirmiştir. Bu gücüyle kadın, eril zihniyet tarafından bereket ve bilgeliğin yanı sıra karanlık özellikleri de bünyesinde bulunduran bir varlık olarak tanımlanmıştır. Kendini kadın ve dünya üzerinde etkin kılmaya çalışan erkek, bu bağlayıcı güçler karşısında kendi ruhsal mitolojik gücünü oluşturmuştur (Stone, 2000, s. 233). Eril zihniyetle şekillenen ve kültürel kodlarla desteklenen mitolojik unsurlar, kadın ve yılan arasındaki ilişkiyi de kendi lehine göre işleyecek biçimde sunmuştur. Şeytan-yılan gibi ayartıcı ve kötülükle bağdaştırılan kadın karakterler eril korkularla ortaya çımış ve anne arketipinin olumsuz yönünün temsili olmuştur (Sivri ve Akbaba, 2018, s. 59).

Yılan, kadın ve şeytan ilişkisinin geleneksel inanç ve anlatılarda pek çok farklı anlamda ve biçimde ortaya çıktı̆̆ı görülmüsstür. Yunan mitolojisinde Medusa, Türk-Anadolu mitolojisinde Şahmeran, İslâm mitolojisinde Belkıs gibi kadın karakterler yılan-kadın ya da şeytan-kadın ilintisinde simgeleştirilmiştir. Adları farklı olsada her biri aynı kimliği temsil etmekte ve bir şekilde Lilithle birleşmektedir. Öte yandan Hint mitolojisinde kaotik bir varlık olarak sunulan Kali; ilk ölümlü kadın, tüm kötülükleri yayan ve erkeğe ceza olarak dünyaya gelen Pandora yine Lilithle özdeşleştirilen kadın karakterlerden olmuştur. Yahudi

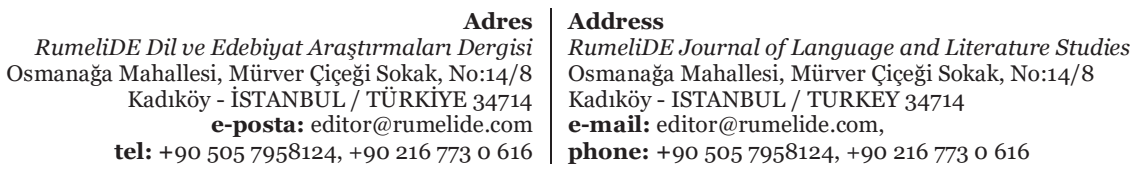


kültüründe ise Lilith, Âdem ve Havva'nın yasak meyveyi yemesi ve cennetten kovulmasına neden olan kötü bir metafor olarak ortaya çıkmıştır. Lilith'in yılan-şeytan-kadın birleşimi olarak ilk günahın işlenmesinde aktif rol aldığı tasvir edilmiştir. Lilith, çoğunlukla yaptığı kötülüklerden güç alan kadınların temsili olarak yer almıştır. Lilith ve benzeri kadın imajlarının ele alındığı anlatılarda çoğunlukla Tanrıların ya da erkeklerin çektikleri güçlüklerin betimlemeleri yer almıştır. Eril zihniyetin şekillendirdiği, kadının kötücül bir varlık olduğu görüşüne eklemlenen ve pek çok yönden aynı kaderi paylaşan bu arketipler tarihin lanetlileri arasında yer almışlardır. Ataerkil güç kendi kontrolü altına alamadığı kadınları bu şekilde kötü formlarda yansıtmıştır. Bugünkü kadın algısının temelini oluşturan bu arketipler, mitsel anlatılar yoluyla nesilden nesile aktarılmıştır. Ana Tanrıça kültüne de yakın bir figür olan Lilith, 'ilk ana' ya da 'ulu ana' olma özelliği taşıyan ve yaratılış mitlerinde yer alan Tiamat, Namnu, Umay, Ayzıt, İnanna, Kibele, İsis, Afrodit, Artemis gibi pek çok Tanrıçayla da örtüşmektedir (Zingsem, 2007, s. 15; Çınar, 2018, s. 370-380; Oylubaş, 2013, s. 438; Yeniçeri vd., 2015, 1036-1037; Özbay, 2013, s. 54; Erhat, 2018, s. 162). Ana Tanrıça kültünün bünyesinde barındırdığı yaratıcılığı ve yok ediciliği içeren nitelikler Lilith’in de özellikleri arasında tasvir edilmiştir (Jung, 2013, s. 22-40). Lilith'in mitolojilerdeki formları benzerliklerle doludur aynı zamanda bedensiz ve belirsizdir. Lilith, yüzyllar içinde toplumlar tarafından farklı adlarda ve biçimlerde sunulmuştur. Lilith'in sosyal temsiline bakıldığında daha çok kötü ruhsal güçlerle bağdaştırılarak olumsuz niteliklerle donanmış formlarda yer aldığı görülmüsstür. Öyle ki Lilith’in cinselliğe olan düşkünlüğü, intikamcı yapısı, baştan çıkarıcıllğı en belirgin özellikleri olarak vurgulanmıştır. Lilith'in hikayesinin geri kalanı göz ardı edilmiştir. Kadın cinsiyetine atfedilen ahlaki normlara ve toplumsal cinsiyet rollerine uymayan kadın temsilleri tarih boyunca hem ulaşılamaz bir arzu hem de bir aşağılanma nesnesi konumunda yer almışlardır.

Mezopotamya mitolojisinde Lilith'in Ana Tanrıça İnanna bir diğer adıyla İştar etrafında şekillenen anlatılarla paralellik gösterdiği görülmüştür. Tanrıça İnanna eril ve dişil pek çok nitelikle donanmıştır. Gök ve yer kraliçesi olarak tanımlanan İnanna bir taraftan özgürlük, aşk, bereket ve doğurganlığı temsil etse de diğer taraftan savaşçı, gaddar, güzelliğiyle baş döndüren, kıskanç ve şehvetli bir yapıda tanımlanmıştır (Schimel, 2004, s. 230). İnanna’nın sıfatlarından biri Kutsal Fahişe'dir. Tanrıça İnanna’ya ilişkin M. İ. Çı̆̆ (2005), Sümerlerde tapınak fahişeliğinin kadınların görevlerinden sayıldığını ve tapınaklarda yaşanan cinsel birlikteliğin kutsal olduğunu belirtmiştir. O dönemde, İnanna'nın temsilcileri olan Kadiştu/İşartu'lar -kutsal kadınlar- toplumun kutsal mekânları saylan tapınak sitelerinde -Tanrıça'nın kutsal evi- bir arada yaşamışlardır. Tanrıçalarına saygılarını göstermek için topluluktaki erkekler arasından seçtikleriyle tapınakta cinsel birlikteliğe girmişlerdir. Çocuklar doğurarak onları tapınağa bağışlar bir nevi Tanrıça'ya hediye sunarlarmış. Tanrıça İnanna’nın cinsel yaşamının kutsallaştırıldığı eski Sümer kaynaklarında kutsal kadınlarla ilgili hikâyelerden biri olan İnanna ile Enki anlatısında genç bir kız betimlemesiyle adı geçen Lilith, 'Inanna'nın eli' olarak tanımlanmıştır. Lilith'in, İnanna tarafından gönderildiği ve sokaktaki erkekleri toplayarak tapınağa getirmek üzere görevlendirildiği belirtilmiştir (Uraz, 1994, s. 77-78; Stone, 2000, s. 182). Burada Lilith İnanna'ya sadakatlerini gösteren kutsal kadınları ve doğurgan kadın imajını temsil eden sembol olarak görülebilir. Ana Tanrıça İnanna'nın kutsal sayıldığı dönemlerde kendisine sunulan 'Kutsal Fahişe' sıfatı saf ve lekesiz kadınları temsil etse de zaman içinde Tanrıça tarafından görevlendirilen ve kutsal evlilik yoluyla doğurganlığın artırılmasına hizmet eden kutsal kadınlar, Eril Tanrı’nın Tanrıçaya karşı güç kazanmaya başladığı dönemlerde artık babası belli olmayan çocuklar doğurarak evlilik dışı cinsel birlikteliği ve ahlaksızlığı temsil eden varlıklar olarak nitelendirilmiştir. İnanna erkekleri cinsel eylemlere kışkırtarak kendisine bir beden oluşturmaya çalışan ve birlikte olduğu erkeklerin hayatlarına kötülük getiren bir figür olarak görülmüştür. İnanna ile özdeşleşen Lilith ise, eril yapının kadına yüklediği ahlaka karşıt olarak var olan mitolojik bir figür haline gelmiştir. Lilith'in, babası belirsiz çocuklar ve cinler yaratmaya çalıştı̆̆ına yönelik bir uyarı niteliğinde ve ondan sakınılması gerektiğini

\footnotetext{
\begin{tabular}{r|l} 
Adres & Address \\
RumeliDE Dil ve Edebiyat Araştırmaları Dergisi & RumeliDE Journal of Language and Literature Studies
\end{tabular}

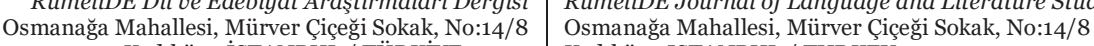
Kadıköy - İSTANBUL / TÜRKIYE 34714 Kadıköy - ISTANBUL / TURKEY 34714 e-posta: editor@rumelide.com e-mail: editor@rumelide.com, tel: +90 5057958124, +902167730616 phone: +90 505 7958124, +90 2167730616
} 
vurgulayan anlatılar ortaya çıkmıştır. Lilith bir nevi İnanna’nın negatif yönünün temsili olmuştur (Çınar, 2018, s. 369). Lilith’in kendisine biçilen bu olumsuz kimliği zamanla pekiştirdiği görülmüştür. Mitolojik unsurların yoğunlukta olduğu eski Yunan medeniyetinde de kadınların belirli açılardan olumsuz yönlerle algılandı̆̆ı görülmüştür. Bu dönemde kadın dünyaya kötülük yayan, erkeğin hizmetinde olan ya da erkeği aşağı çeken olumsuz bir varlık olarak tanımlanmıştır (Estin ve Laporte, 2002, s. 56-59). Yine bu dönemde, cinselliğin kutsal olandan uzaklaştırdığı düşüncesi sebebiyle kadınlarla cinsel birliktelik kötü olarak yorumlanmıştır. Lilith'in başlangıçtaki olumlu gücünün aksine zamanla olumsuz niteliklerle çevrili bir karaktere evrildiği görülmüştür. Lilith, başlarda saf, kutsal ve güçlü bir figür olarak varlık sürdürse de toplumlarda eril zihniyetin hüküm sürmesiyle birlikte cinselliğe düşkün, intikamcı yapıda, baştan çıkarıcı, bebek katili ve cin-şeytan gibi formlara bürünmüştür. Bu değişim Tanrıça statüsündeki düşüşle benzer bir durumdur. Toplumlarda ataerkil düzenin yerleşmesiyle kutsal olan erkek eline geçmiştir. Tanrıçalar da önemini yitirerek artık olumsuz sıfatlarla anılmaya başlanmıştır. Ana Tanrıça kültünün önemini yitirmesi Tanrıçalık vasfına yakın bir figür olan Lilith’in kutsallık, doğurganlık ve bereketi temsil eden olumlu nitelikleri zaman içinde cinsel düşkünlüğe ve gayrı meşru soya dair eril korkulara dönüşmüştür.

Lilith’in İbrani mitolojisindeki görünümü çok daha farklı olmuştur. Lilith artık: “Âdem’in cinsel açıdan kendisine boyun eğmeyen ilk karısının adı olarak çıkar; bu ad daha sonralarıysa ortalığa saçılan spermleri elde etmek için havada bekleyen cinin adı olur" (Stone, 2000, s. 182). Yahudi kültürüne dayanan Ben Sira Alfabesi Lilith’in Adem’in ilk eşi olduğuna dair bilgileri içeren en eski kaynak olarak görülmüştür. Buna göre:

“Tanrı ilk insanı yarattı̆̆ında şöyle konuştu: ‘İnsanın yalnız olması iyi bir şey değil.’ Ve ona topraktan bir eş yarattı -ona benzeyen- adı Lilith olan. Kısa süre sonra birbirleriyle kavga etmeye başladılar: Kadın erkeğe şöyle dedi: 'Ben senin altında yatmak istemiyorum.' Ve ilk erkek karşılık verdi: 'Ben senin altında değil, üstünde yatmak istiyorum; çünkü sen altta kalan olmayı hak ediyorsun ve ben üstün olmayı hak ediyorum.’ Kadın karşılık verdi: ‘İkimizde eşitiz; çünkü ikimiz de topraktan yaratıldık.' Ve her ikisi de birbirlerini anlamayı reddettiler" (Zingsem, 2007, s. 36).

Yaratılan ilk kadın olma misyonuyla Lilith bu metinde ilk defa tam bir kişisel karaktere bürünmüştür (Patai, 1994, s. 205). Bu anlatımda, eşitlik söyleminin Adem tarafından kabul görmemesi üzerine Lilith’in, Tanrı'nın bilinmeyen adını söyleyerek var olan konumundan ayrıldığı ve Samael adlı bir iblisle birlikte olduğu, ondan cin-iblis karışımı çocuklar doğurduğu anlatılmıştır. Bunun üzerine Adem, Tanrı'dan Lilith'in geri gelmesini talep etmiştir:

\begin{abstract}
“Tanrı, Lilith’in peșinden üç melek gönderdi. (...) şöyle konuștu: 'Geri dönmek istediği takdirde, tamam; ama istemezse, her gün yüz oğlunun ölümüne şahit olmayı göze almalıdır.' Melekler kadını bulup Tanrı'nın sözlerini ilettiler. Ama o geri dönmek istemedi. 'Seni denizde boğacağız!' dediler. Kadın: 'Beni yalnız bırakın; çünkü ben çocukları zayıf düşürmekten başka bir işe yaramam: erkek çocukları doğumlarından sekizinci günlerine, kız çocuklarını ise doğumlarından yirminci günlerine kadar gözetmem emredildi.' (...) böylece kadın günbegün şeytanlarından yüz tanesinin ölmesini göze aldı" (Zingsem, 2007, s. 36-37).
\end{abstract}

Adem'den ayrılışının bedeli olarak Lilith'e ceza verildiği görülmüştür. Bu anlatıda baskı uygulayan taraf erkek olmasına karşın cezalandırılanın kadın olması dikkat çekmektedir. "Lilith'e verilen ceza kadınlar ataerkil normlara ve kültürel ritüellere uymazsa ne olacağını gösteren sembolik bir eylemdir. Kendini gerçekleştirmeye çalışan kadınlara bir uyarıdır. Özgürleşmeyi talep ederlerse, onları kötü eylemciler yapacak erkek egemen toplum tarafından dışlanacaklardır" (Yeniçeri vd., 2015, s.1037). Kadının yaşam içerisinde bir özne olarak var olma çabasını içeren davranışlar ataerkil egemen kültürde bir başkaldırı olarak görülmekte ve bu çaba içerisindeki kadınlar toplumdan dışlanarak

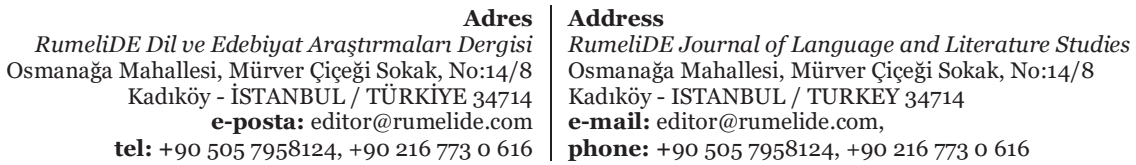


516 / RumeliDE Journal of Language and Literature Studies 2022.26 (February)

A feminist perspective on perception of women in mythology and religions through the figure of 'Lilith' / / S. C. Yeter; K. Özcan (pp. 506-525)

cezalandırılmaktadır. Gilbert ve Gubar' a göre (2016) Lilith, kadının kendini gerçekleştirme serüveninde ödemesi gereken bedellerin temsilidir.

Lilith’in kaçışı, şeytani bir isyandan ziyade kadın cinsiyeti üzerindeki eril tahakkümü reddetme ve ondan ayrılma çabasıdır. Lilith kendi iradesi dışında kovulmuş ya da dışlanmış değildir. Lilith, Adem'in kendisine eşit davranmayacağını anladığında onun yanından ayrılmayı seçmiştir. Lilith erkeğin belirlediği beklentiler tarafından baskı altına alınmayı reddettiği için tehdit ve cezalandırmayla karşı karşıya kalmıștır (Basmacı, 2021, s. 7). Lilith'in konformite olmayan bu tavrı ondan iğrenilen, kaçınılması gereken ve itaatsiz bir kadın figürü hâline gelmesine neden olmuştur. Lilith pek çok dini mitolojik anlatıda kötülük ve baştan çıkarıcı özelliklerle yılan ve şeytanla özdeşleştirilmiştir. Lilith'in cesaret, tutku, ego gücü ve arzu gibi tüm değerleri göz ardı edilmiştir. Bu anlatıda kadının Tanrı'nın bilinmeyen adını söyleyerek cennetten uzaklaştığı görülmüştür. Kadının Tanrı'nın gizli adını bilmesi ve onunla dolaysız iletişim kurabilmesi eril zihniyet tarafından kabul edilebilir bir durum olarak görülmez (Yeniçeri ve vd., 2015, s. 1036).

Ç. Akyıldız (2013), ataerkil anlayışa göre gökyüzü ve yeryüzünün iki ayrı uç olduğunu belirtmiştir. Dişil güç toprak ve yeryüzüyle eril güç gökyüzüyle bağdaştırılır. Yeryüzünün doğurganlık ve üretkenlik özellikleri bulunur ve bu özellikler kadın cinsiyetine uygun görülür. Fakat yeryüzünün ölüm, lanet, kötülük, gizlilik gibi bazı olumsuz özellikleri de vardır. Eril olanla ilişkilendirilen gökyüzü ise kutsal olanı ve kutsal olanın saflığını bir arada bulundurur. Bu anlatıda Adem’in cinsel ilişki sırasında toprağı temsil eden kadının altta, gökyüzünü temsil eden erkeğin ise üstte kalmasına ilişkin isteği feministlerce Adem'in cinsel narsizmi olarak yorumlanmaktadır (Öztürk, 2004, s. 159). Adem, zeki ve cinsel olarak aktif bir kadınla sevişme konusundaki yetersizliğini kadının üzerine yükleyerek ona bir nevi baskı uygulamaktadır. Ancak Lilith bu zorlayıcı sevgiyi reddetmektedir. Tanrıçalık döneminde kutsal kadınlar olarak belirtilen kadınlarında benzer cinsel birliktelik anlayışları olduğu söylenebilir. Cinsel birliktelik esnasında partnerinin otorite dayatmasına direnen Lilith, kadının erkeğe tabi olduğu anlayışına sahip ataerkil toplum yapısı içindeki masumiyet ve itaat merkezli kadın arketiplerine uygun değildir. Lilith yalnızca cinsel manada Adem'in zirvede olmasını reddetmekle kalmayı her koşulda eşit olduklarını savunmaktadır. Bu yönüyle Lilith, geleneksel anlayışı yıkan ve erkek egemen dünyaya başkaldıran bir tavır sergilemektedir (Çınar, 2018, s. 384; Karaca, 2019, s. 121). Eril zihniyet bu durumu erkekliklerini kurtarmak için kendi çıkarları çerçevesinde yorumlayarak Lilith’e dair olumsuz algı oluşturdukları söylenebilir.

Ataerkil tanımlara göre Tanrı, Lilith’in geri dönmeyeceğini anlamış ve Adem’in yalnız kalmaması için onun kaburga kemiğinden Havva'yı yaratmıştır (Ünal, 2017, s. 108-111). Bu anlatının eski yaratılış hikâyelerinden olan Ay-Atam ve Ay-Wa anlatısıyla benzerlik içerdiği görülmüştür. Bu anlatıya göre, erkek ve kadın çamurdan yaratılmıştır. İlk yaratılan erkek olmuştur. Kadın da çamurdan yaratılmış olsa da yaratılış esnasında güneş ısısı yeterince olmadığı için yarım kalmıştır (Borotav, 2012, s. 36). Havva'nın Adem'in kaburga kemiğinden yaratılması kadın ve erkeğin varoluşları açısından eşit olamayacaklarına yapılan bir vurgu niteliğindedir. Bu hikâyede, kadının zayıf ve erkeğin aşağısında yaratılması yönündeki algı kadın ve erkek arasındaki tahakküm ilişkisini biyolojik gerekircilikle genetik koda havale etmiştir. Kaburga kemiğinden yaratılma hikayesinde Adem, kadının doğurganlık işlevini kendi üzerine alarak yaşamın yaratıcısı rolünü üstlenmiştir. Erkeği doğuran kadın değil esasında kadın erkekten doğmadır. Çünkü kadın erkeğin bedeninden yaratılmıştır. Erkeğin bir parçası olan kadın tek başına bir değere sahip değildir. Kadın erkeğin isteklerini ve ihtiyaçlarını karşılamak için yaratılmıştır (Zingsem, 2007, s. 153-154). Bu durum kadının gizemli gücüne yönelik oluşan korkunun yansımasının ve kendini ispat etme çabasının bir parçası olarak değerlendirilebilir. Lilith’in kutsal annelik gereği

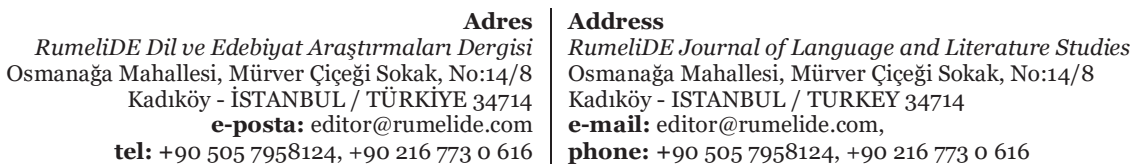


zorunlu görülen annelik görevini reddetmesi, cinsel olarak aktif olması ve monogamiye uymayan hâlleri ataerkil normlara ters düşmektedir. Lilith’in aksine Havva itaatkâr, saf, zayıf, cinsel olarak pasif ve erkeğin soyunu devam ettirmeye istekli bir kadındır. Bu yönleriyle Havva, ataerkil ideolojinin ideal kadını konumundadır. Havva, Adem'in hayalindeki kadının özelliklerine sahip olduğu söylenebilir. Günümüzde de kadını ikincilleştiren ve tahaküm ilişkisini sürdüren eril zihniyetin edilgen, uyumlu, ağırbaşlı ve erkeğe muhtaç olma gibi kadına atfettiği rollerin benzerliği dikkat çekmektedir. Eril zihniyete göre kadın eşini mutlu etmeli, kendini evine, kocasına ve çocuklarına adamalıdır. Eril bakış açısına göre, aksi yöndeki tutum ve davranışlar kadınları Lilith ile birleştirmektedir.

Ben Sira Alfabesi'ndeki anlatıya dayalı olarak Yahudi kutsal metinlerinde de birtakım referanslar bulunmaktadır. Tevrat'ta kadının yaratılışına ilişkin iki anlatı yer almaktadır. Tekvin 1. Bab'da, Tanrı insanı kendi suretinde erkek ve dişi olarak yarattı ve onlara "...çoğaln, yeryüzünü doldurun ve onu tâbi kılın...” (Kitab-ı Mukaddes: Tekvin Bab 1) diyerek seslendi. Diğer bir anlatı olan Tekvin 2. Bab'da ise, “... Allah dedi: Adamın yalnı olması iyi değildir; kendisine uygun bir yardımcı yapacağım. ...adamın üzerine derin uyku getirdi. [Onun] ...kaburga kemiğinden bir kadın yaptı ve adam getirdi...” ifadeleri yer alır (Kitab-ı Mukaddes: Tekvin: Bab 2). Bab 1'de cinsiyet ayrımcllı̆̆ı gözetilmediği görülmüştür. Bab 2'deki anlatıda ise kadına erkeğe yardımcı olma vasfı yüklenmiş ve kadının erkekten yaratılması onu erkeğin aşağısında konumlandırmıştır. İlk anlatıda, kadın ve erkeğin eş zamanlı olarak topraktan ya da tozdan yaratıldığı belirtilse de ikinci anlatıda kadının erkeğin kaburga kemiğinden yaratıldığı görülmüştür. Bu yaratılış hikâyeleri birbirinden farklıdır çünkü birincisi insanların eşit yaratıldığını gösterir. İkincisi ise ataerkil bir temaya sahiptir. Havva'nın Adem'in kaburga kemiğinden yaratılması hadisesine dair Kur'an'da doğrudan böyle bir ibare yer almamakla birlikte, Tevrat'ın bir bölümünde, bazı hadis ve tefsir yorumlarında yer alan ifadeler bu konuya ilişkin iddiaları genel bir kabule dönüşmüştür (Şahin ve Toprak, 2016, s. 206-207; Ünal, 2017, s. 105). Kur'an'daki "Ey insanlar! Sizi bir tek nefisten yaratan ve ondan da eşini yaratan ve ikisinden birçok erkekler ve kadınlar üretip yayan Rabbinizden sakının" (Maide, 4/1) ayetinin de bu bağlamda yorumlandığı görülmüştür. Ancak modern yaklaşımda, 'tek bir nefs' ifadesinin aslında kadın ve erkek için aynı şeyi ifade ettiği iki cinsiyetin de tek bir özden yaratıldığı şeklinde yorumlanmıştır (Palabıyık, 2020). Yaratılış anlatılarında geçen 'Âdem' ifadesinin insan anlamına geldiği bilinmektedir. İnsan ya da Tanrı kavramlarının kaynaklarda erkekle özdeşleştirilmesi, kadının varoluşunu eşit konuma getirmesi konusunda ortaya çlkan en temel sorunlardan biridir.

Lilith, ilk günah anlatılarında Adem'i günaha sürükleyen Havva'ya yasak meyveyi veren kişi olarak tasvir edilmiştir. Yahudi-Hıristiyan anlatılarına göre Lilith (yılan-kadın-şeytan) ya da sadece biri, Havva’yı yasak meyveyi yemesi konusunda kandırır. Havva' da bilahare Adem'e bu meyveyi yedirince cennetten kovulmalarına sebep olur. Bazı anlatılarda ise, Havva ile Lilith'in işbirliği yaparak Adem'i kandırdıkları ileri sürülür. Burada, cennetten kovuluşun sebebi olarak bir şekilde kadın sorumlu tutulur. Kur'an'da ise bu olay doğrudan şeytan ile bağdaştırılır (Özbay, 2013, s. 42-45). “Âdem’in cennetten kovulmasının sebebi olarak kadının görülmesi baştan çıkarıcılı̆̆ıla ilişkilendirilir. Buna göre kadın, sırf kadın olduğu için ayartıcı ve baştan çıkarıııdır dolayısıyla baştan da çıkabilir” (Palabıyık, 2020). Bu sebeple kadınlar tehlikeli ve kontrol edilmesi gereken varlıklar olarak görülmüştür. Kadınlara yönelik oluşan bu negatif algı yüzyıllar boyunca onların hayatlarını etkilemiş ekonomik, sosyal, aile hayatında olumsuz izlerini sürdürmeye devam etmiştir. Bu cinsiyetçi yorumların toplumsal hayata yansımaları kadınların aleyhine olacak şekilde yer almıştır. Tarihsel süreç boyunca kadının eğitilmesine, erkekten bağımsız bir konuma getirilmesine ve ayartıcılı̆̆ına izin verilmemesi gerektiği vurgulanmıştır.

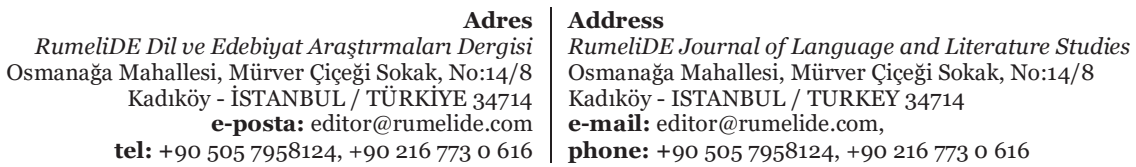


İlk günah anlatılarında kadın suçlu ya da ilk günahı işleyen kişi olarak tasvir edilmiştir. Adem ise aldatılan ve baştan çıkarılan taraf olmuştur. Başlangıçta ayrışmamış bir bütünün iki parçası olan Adem ve Havva ilk günahı işleyene kadar uyum içindedir. Yapılan itaatsizlikle birlikte bozulan düzende kadının baş suçlu ilan edilmesi bir kaosu da beraberinde getirmiştir. İlk günahla birlikte kadın ve erkek artık cinsiyetlerinin ve cinselliklerinin bilincine varmıştır. Cinsel uyanışla birlikte kendinden olanı yaratmak için kadının bedeni ve doğurganlığına muhtaç olduğunu gören erkek, kadının doğurganlığı üzerine hakimiyet kurma çabasına girmiştir. Yasak meyvenin yenmesiyle her şeyin mükemmel olduğu düzen artık yaptıkları hatanın bedelini ödeme mücadelesine dönüşmüştür. İnsan artık iyi ve kötünün, ölüm ve yaşamın farkına varmıştır (Akdeniz, 2017, s. 703).

Toplumlarda var olan cinsiyet ideolojisinden etkilenen Havva ve Lilith, birbirinden farklı karakterler olarak görülmektedir. Havva, erkeğin kaburgasından yaratılan ve onun iktidarını kabullenmek zorunda kalan saf ve itaatkâr bir karakter iken Lilith ise, erkekle eşit şartlarda yaratılan ve daha çok kötü bir karakter olarak lanse edilen özgür ve güçlü bir kadındır. Dede Korkut Destanı ve Köroğlu Destanında kadınların kahramanlıklarının yanı sıra iyinin, kötünün temsili olarak yer alan İpek kadın ve Köpek kadın imgeleri bir nevi Lilith ve Havva'nın destanlardaki görünümleri olarak düşünülebilir (Gazanfergizi, 2019, s. 127-128). Geleneksel tanımlarda Lilith’in Havva ile Adem arasındaki ilişkiyi kıskandığı belirtilmiştir. Modern şeklinde ise, Lilith ve Havva arasındaki gerçek ilişkinin düşmanlıktan ziyade kardeşlik ilişkisini içerdiği ileri sürülmüştür. Beğenç (1974) yasak meyve anlatılarında, sonsuz yaşamın sembolü olarak görülen elmanın -bilme meyvesi- öncelikli olarak kadına sunulmasının ona anneliği ve doğurganlı̆̆ bahşettiğinin bir simgesi olduğunu ifade etmiştir. Mitolojik ana kompleksiyle ilişkili olan Havva'nın kelime anlamının yaşam ya da hayat vericilik olduğu düşünüldüğünde bu savı desteklediği düşünülmektedir.

Antik dönemde Lilith'in kötü ya da şeytan olduğuna ilişkin anlatılardaki olumsuz algı Yahudilikle daha da yaygın hâle gelmiştir. Talmud'da Lilith, uzun saçlı, kızıl ve insan yüzlü olarak tasvir edilmekte, gece iblisi ya da erkekleri baştan çıkarmak için geceleri erkeklerin rüyalarına giren iblis olarak anlatılmaktadır. Talmud ve Zohar'da Lilith, lohusa kadınları ve bekâr erkekleri etkisi altına aldığı için dikkat edilmesi gereken bir varlık olarak yer almıştır. Erkekleri rüyalarında rahat bırakmadığı ve onları baştan çıkardığı belirtilmiştir. Bu sebeple Yahudilerde erkeklerin yalnız yatmaması gerekliliği ön görülmüştür (Ünal, 2017, s. 105-108). Bu durum Lilith'e dair toplumsal kolektif bilinçaltına yerleşmiş bir kötüleme olarak yorumlanabilir. Metamorfik açıdan 'gece' uğursuzluğu ve tekinsizliği belirtmektedir. Lilith’in gece iblisi olarak tasvir edilmesi kadınlara duyulan güvensizliğin bir yansımasıdır.

Eril anlatılara göre Adem'in soyundan gelen çocukları kıskanan ve kendi cin çocuklarının öldürülmesinin intikâmını almak isteyen Lilith, hamile ve lohusa kadınlara musallat olan bir forma bürünmüştür (Karaca, 2019, s. 120-122). İsmen aynı olmasa da bir metafor olarak mitolojide Lilith'in kadınlara ya da bebeklere musallat olma özelliğiyle ilişkilendirilebilecek birçok figür olduğu görülmüştür. Türk mitolojisinde Alkızı/Alkarası/Albastı (Kılıç ve Eser, 2018, s. 54-56; Gazanfergizi, 2019, s. 131). Mezopotamya'da Tiamat, Akatta Lamuşthu ve Yunanlarda Lamia gibi mitolojik karakterler bebek katili ya da dişi şeytan olarak nitelendirilmişlerdir. Bu kadınlardan korunmak için kullanılan nazar boncuğu, ayna, okunmuş arpa, tılsım yöntemlerin kökeni Lilith'e kadar dayanmaktadır. Bu uygulamalar, Lilith’ten korunmak için uygulanan geleneksel ritüellerle bağdaşmaktadır (Akylldı E., 2013, s. 95).

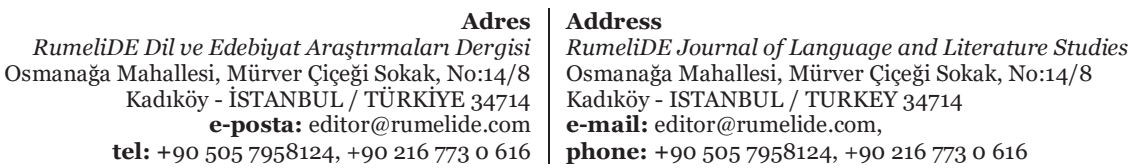

RumeliDE Journal of Language and Literature Studies

Osmanağa Mahallesi, Mürver Çiçeği Sokak, No:14/8

Kadıköy - ISTANBUL / TURKEY 34714

e-mail: editor@rumelide.com,

phone: +90 5057958124, +90 2167730616 


\section{Lilith’in çağdaș sanat ve edebiyattaki görünümü}

Farklı bakış açılarıyla yorumlanabilen karmaşı yapıya sahip bir kültür olgusu olan mitin, geçmişten günümüze toplum içinde yerleşmiş olan kolektif bilinçdışı düşünce ve yargıları anlamadaki etkisi önemlidir. Çünkü mitolojik anlatılardaki düşünce ve semboller, gelenek ve göreneklerin biçimlenmesinde oldukça etkilidir. Sanatçılar ve yazarlar, bugünün izlerini anlayabilmek için mitolojik sembolleri dönüp sorgulanması gereken önemli kaynaklar olarak görmektedirler. Ayrıca sanatçılar ve yazarlar mitolojik kaynaklardan yararlanarak geçmiş ile bugün arasında ilişki kurma, gerçekliklerini bulma ve yeni anlamlar üretme yoluna giderler (Chatzoudas M., 2018, s. 1082-1085).

Özellikle kadın olgusu açısından bakıldığında mitoloji, ataerkil düzende toplumsal cinsiyet rollerini oluşturmak ve benimsetmek için kullanılan önemli bir araç olarak ortaya çıkmaktadır. Sanat ve edebiyatın da, 'toplumsal cinsiyet ideolojisine' hizmet ettiğinin örneklerini bazı eserlerin betimlemelerinde gözlemlemek mümkündür. Sanat, edebiyat gibi birçok alanda mitolojik unsurlara yoğun göndermeler, manidar simgeleştirmeler ve metaforlarla karşılaşılmaktadır (Özbay, 2013, s. 4850). Kadınlık olgusunun tarihsel süreçteki izlerini sorgulayan sanatçllar, mitolojik figür ve anlatıları kendilerine yol gösterici olarak seçerler. İlk kadının yaratılışından bu yana kadının özünü ve bedenini konu alan yerici-övücü niteliklerde sanat eserleriyle karşılaşmak mümkündür.

Kutsal metinlerde ilk günahın işlendiği ‘yasak meyve’ye ilişkin anlatılarda, Havva'nın yılan- şeytankadın birleşimi olan canlıyla ilişkisi farklı varyasyonlarda anlatılsa da temel olarak kadının özüne ilişkin negatif bir algının yüklendiği görülmektedir. Bu algının oluşmasında eski mitolojik söylenceler ve ataerkil zihniyetin payı büyüktür. Kutsal metinlerde ve mitolojik söylencelerde kadınlarla kötülük arasında kurulan bağ -yılan-şeytan-kadın (Lilith) bileşimi- bazı sanat eserlerindeki figürler ve edebi metinlerdeki ifadelerle belirginleştirilmiştir. Bu konuya ilişkin oluşan toplumsal bilinçaltının izleri eserlerde farklı şekillerde yerini almıştır. Dini mitolojik öğretilerde yılan-kadın ya da yılan-şeytan şeklinde tasvir edilen Lilith ile sanat eserlerindeki betimlemeleri arasındaki benzerlikler dikkat çekmektedir. Michelangelo'nun 'ílk Günah ve Cennetten Kovuluş' adlı betimlemesinde (Ek, 1), bir incir ağacı görüntüsüyle resmedilen bilgelik ağacı, sahneyi iki eşit parçaya bölmüştür. Ağacın izleyiciye göre sol kısmında ilk günahın işlendiği an betimlenirken; sağında ise cennetten kovulma sahnesi işlenmiştir. Resmin tam ortasında, Lilith’e özdeş 'yllan-kadın' yer almaktadır. Resme bakıldığında, yılan-kadın figürünün yasak meyveyi Havva'ya uzattığı görülmektedir. Ancak Âdem’in de istekli bir şekilde ağaca doğru yöneldiği görülmektedir. Michelangelo'nun burada, bütün suçun kadında (Havva) olmadığını, erkeğin de suçun bilinçli bir parçası olduğunu vurgulamaya çalıştı̆ı düşünülebilir. Ancak söz konusu resimde şuna da dikkat etmek gerekir ki; Havva yaşanan olaylardan bihaber olarak görülse de Lilith her ikisi için de tehlike unsuru olarak tasvir edilmiştir (Özbay, 2013, s. 53; Akdeniz, 2017, s. 705). Lilith kötü kadını; Havva ise iyi kadını çağrıştırır. Hugo van der Goes'in "Düşüş” adlı eserinde (Ek, 2) Lilith, kutsal metinlerde yer alan yasak meyveyle kandırma anlatılarındaki baştan çıkarıcı, yıkıcı betimlemelerin aksine; ağaca tutunmuş bir şekilde Havva ve Âdem'i kıskançlık ve keder içinde seyreden, görsel olarak çirkinleştirilmiş bir şekilde işlenmiştir. Tiziano Vecellio'nun, 'Âdem ile Havva' adlı eseri (Ek 3), Yahudi kutsal metinler ve mitolojik öykülerle inşa edilen baştan çıkarıcı, kötülüğe meyilli, itaatsiz kadın imgesini destekleyici niteliktedir. Eser, ilk günaha dair anlatılara sadık kalarak hem Havva'yı hem de Lilith'i tüm kötülüklerin sorumlusu olarak göstermiştir. Âdem ise, iki kötü kadın arasında kalmış bir kurban olarak tasvir edilmiştir (Akdeniz, 2017, s. 704). Lilith'i feminist bakış açısıyla ele alan Kiki Smith 'Lilith' adını verdiği heykelde (Ek, 4), kadın imgesini bir kadının gözünden yeniden inşa etmiştir. Eserde Lilith, "duvarda çömelmiş olarak baş aşağı yerleştirilmiş, korkutucu bakışlarını izleyiciye yöneltmiştir” (Chatzoudas M., 2018, s. 1083). Bu

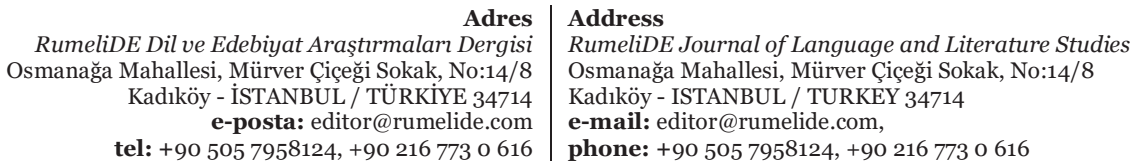


heykelde Lilith, eril ideolojinin kadının varoluşu sebebiyle itaatsiz, saf, zayıf iradeli olduğu düşüncesine boyun eğmeyen güçlü ve özgür bir figür olarak gösterilmiştir. Öte yandan hassas bir kadının varlığı ortaya çıkarılmıştır. Heykelde Lilith istenen ve istenmeyen tüm özellikleriyle bir arada sunulmuştur. Lilith buradadır. Kendini bize gösterir ve cesaretini bize hatırlatır. Kadının güçlü ve bağımsız olma isteğini temsil eden kadın kimlikleri eril ideoloji tarafından dışlanmakta ya da bertaraf edilmektedir. Ancak bu heykel her şeye rağmen kadının özünden ve cesaretinden vazgeçmemesi gerektiğini vurgular niteliktedir.

Edebiyat alanında da Lilith ile ilişkilendirilen birçok karakter yer almaktadır. N. Nazım'ın 'Zehra' romanındaki Zehra karakteri, annesi ölmüş, zengin babasıyla birlikte yaşayan, sonraları ise Suphi adında biriyle evlenen; ihtiraslı, kıskanç ve intikamcı özellikleriyle çevresine zarar veren kimliğe sahip bir kadındır. Zehra, hayatına girdiği insanlara başta mutluluk verse de hırçın, kindar oluşu onu her türlü kötülüğü yapmayı göze alan femme fatale bir yapıya büründürür ve hayatındaki insanlara zarar verecek davranışlar sergiler. Romanda Zehra, "kendisini aldatıp metresine ev açan kocasından ve metresinden intikam almak için parayla başka bir kadın kiralayıp kocasının başına musallat edecek kadar fettan, kötücül, cesur, ekonomik açıdan da güçlü bir kadın..” (Fedai, 2012, s. 86) olarak tasvir edilmiştir. Zehra'nın bencilliği dâhilinde sergilediği davranışlar hayatındaki insanların ölümüne bile sebebiyet verir. Sevgi açlığı, bencilliği ve intikam içeren duygularıyla Zehra tasvir edilen 'Lilith'e benzer şekilde ele alınmıştır. Eşi tarafından aldatılan Zehra'nın intikam ve hırs duygularıyla çevresindekilere zarar vermesi durumu Lilith'in doğurganlı özelliğinin elinden alınması sonrasında, intikam ateşiyle lohusa kadınlara musallat olduğuna ve yeni doğan çocukları öldürdüğüne yönelik anlatılarla metinlerarasılık göstermektedir. Zehra'nın ruh hali kadının özü itibariyle kötücül yapıda olduğu anlayışını vurgular tarzdadır. A. Çınar (2018), Leyla Erbil'in 'Üç Başh Ejderha' adlı romanındaki, yılan saçlı Tanrıça betimlemelerinin manidar simgeleştirmeler olduğunu belirtmektedir. Bu betimlemeleri, yllan-LilithHavva ve Âdem imgeleriyle ilişkilendirir. Söz konusu romanın; kutsal metinler ve mitolojik söylencelerin, erkeğin üstünlüğünü vurgulayan; kadını ikincilleştiren içeriğine karşıt olarak yoğun göndermeler içerdiğini söylemektedir. Ona göre, metinde yer alan yllan metaforları güç ve egemenliğin simgesidir. Bu simgeyi, geçmişten günümüze süregelen fallik hâkimiyet yani erk söyleminin kaynağı olarak görür. Romanda, varoluşun erk (erk- yılan-fallus) ve dişil olanın birbirini tamamlamasıyla gerçekleştiğini ve ikisi arasındaki diyalektik ilişki birinin üstünlük sağlayacağı biçime -iktidar ilişkisinedönüşürse, varoluşun bir çatışma içine gireceğinin vurgulandığını ifade etmektedir. G. Dilmen'in 'Bağdat Hatun' oyununun başkişisi Bağdat Hatun kendi gücünü kullanmak istediği için itaatsizliği, hırsları ve arzuları nedeniyle çevresindekileri felakete uğratan demonik bir kadın olarak kurgulanmıștır. Ataerkil ideolojiyi ve ahlaki değerlerini tehdit eden Bağdat Hatun, arzularını dizginleyemediği için kendi sonunu da hazırlamış olur (Vural, A., 2020, s. 1002). Kadının bir otorite olarak erkeğin karşısında olma isteği eril zihniyet için bir isyan göstergesidir. Eril düşünceye göre kadın erkeğin gerisinde olmalı ve onun dedikleriyle hareket etmelidir. Bu anlayışa karşıt tutum ve davranışlara olumsuz anlamlar yüklenerek kadını kötüleme yoluna gidilmektedir. Fuzuli'nin 'Leyla ile Mecnun' adlı eserinde de Lilith figürüne ilişkin gizli çağrışımlar bulunmaktadır. Leylâ’nın güzelliğinin cazibesi kadar Lilith, kandırılan Havvâ kadar tehlikeli oluşunu Mecnûn üzerinde gösteren sahneler yer almaktadır. Örneğin; "Leylâ'nın, Mecnûn'u delirterek aklını kaybetmesine sebep olması, onun için kabilelerin savaşmaları, Lilith'in dönüştürülen, karanlık tarafı ile bağıntılı düşünülmelidir” (Yılmaz ve Gezer, 2018, s. 7). O. Pamuk'un 'Kırmızı Saçh Kadın' adlı romanında yer alan kadın karakter Gülcihan mitolojide kızıl saçlı, özgür, felaket getiren ve şehvetli olarak tasvir edilen Lilith’in bir yansıması olarak yer almıștır. Gülcihan güzelliğinin bir simgesi olan kızıl saçlarıyla erkekleri kendine hayran bırakan bir kadındır. Kızıl saç cinsel arzunun çekiciliğini yansıtan bir imgedir. Ataerkil ahlak içinde kadının cinselliğine yönelik duygularını dışa yansıtması ve bedenini dikkat çekecek şekilde kullanması hoş karşılanmamaktadır.

Adres $\mid$ Address

RumeliDE Dil ve Edebiyat Araşttrmaları Dergisi Osmanağa Mahallesi, Mürver Çiçeği Sokak, No:14/8 Kadıköy - İSTANBUL / TÜRKIYE 34714 e-posta: editor@rumelide.com tel: +90 $5057958124,+902167730616$

RumeliDE Journal of Language and Literature Studies

Osmanağa Mahallesi, Mürver Çiçeği Sokak, No:14/8

Kadıköy - ISTANBUL / TURKEY 34714

e-mail: editor@rumelide.com,

phone: +90 5057958124, +902167730616 
Kadına atfedilen roller ağırbaşlı ve erkeğin tahakkümü altından çıkmayacak şekilde tanımlanmaktadır. Özgür ruhuyla Gülcihan tıpkı Lilith gibi eril normlara uymayan bir karakterdir (Karaca, 2019, s. 124127).

\section{Sonuç}

Mezopotamya mitolojisi başta olmak üzere pek çok kültürde var olan yaratılış anlatıları ve Tanrıça kültünün etkisiyle gelişen Lilith imgesi, teolojide mit olmaktan syyrılarak kendisine bir kişilik oluşturmuştur. Bazı anlatılarda yaratılan ilk kadın olma statüsünde yorumlanarak sosyolojik olarak da toplum nezdinde bir köken edinebilmeyi başarmıştır. Tanrıçaların hüküm sürdüğü antik dönemde Ana Tanrıça ile bütünleşen Lilith, kutsallıkla bağdaştırılmış ve önemli bir konum elde etmiştir. Zaman içerisinde Eril Tanrı'nın, Ana Tanrıça karşısında güç kazanmaya başlamasıyla birlikte farklı şekillerde yorumlanmaya başlanmıştır. Bu yorumlar ataerkil zihniyet çerçevesinde oluşturularak Lilith’i isyan, öfke, şehvet ve cinselliğin sembolü hâline getirmiştir. Yahudilikle birlikte, bir şeytan metaforunun zirvesine oturtularak femme fatale konuma gelmiştir. Kötü ve dişi bir şeytan olarak nitelendirilen Lilith’in, Yahudi kutsal metinlerinde sıkça işlenir duruma gelmesi oldukça dikkat çekicidir. Yahudi anlatılarında erkeğin üstün oluşu, evrendeki kutsal ve merkezi rolü vurgulanmaktadır. Lilith imgesi üzerinden ise kadının itaatsiz, suçlu ve cezalı rolü belirginleştirilmektedir. Lilith figürüyle kadının kötülükle eşitlenmesi ve toplumdan soyutlanması eril toplumların çok da şikâyet ettiği bir durum değildir. Kadına yönelik olumsuz algı dini metinlerinde işin içine girmesiyle sorgulanmayan ya da sorgulanmak istenmeyen bir konu hâline gelmiştir. Eril yapıyı içinde barındıran toplumlar, dini bir araç olarak kullanarak kadınlar üzerinde baskı oluşturmaya çalışmışlardır. Günümüzde ise bu negatif algı ve cinsiyetçi yaklaşımlar birçok kadın tarafından kabul görmemekle birlikte ataerkil düzene karşı bir direniş başlatılmıştır. Lilith, feministler tarafından erkek otoritesine başkaldıran, özgürlüğü için savaşan ilk kadın olarak kabul edilmiştir. Lilith onlar için erkek egemen toplum karşısında boyun eğmekten kurtulmaları için bir sembol olmuştur.

Ataerkil ideolojinin var olduğu hemen her toplumda kadınların, erkeklerin bir adım gerisinde yer aldığı aşikârdır. Belirli durumlarda kadınlar pozitif konumlarda yer alsalar da (aile içinde ve annelik rolünde) birçok açıdan negatif algının hâkim olduğu söylenebilir. Kadına yönelik negatif algının kutsal metinler kaynaklı olduğu düşünülse de esasında bu algı daha da eski dönemlere dayanır. Yaratılıştan bu yana çeşitli formlarda varlığını sürdüren bir arketip olan Lilith, toplum düşüncesinin arka planını yansıtır. Kadın bedenini, cinselliğini ve yaşamını kontrol edebilmek amacıyla dini mitolojik anlatıları baskılama aracı olarak kullanan ataerkil ideoloji için Lilith figürü önemli bir konumdadır. Erkeğin kadından üstün olduğu görüşünü besleyen ve ataerkil ideolojinin sürdürülmesine zemin hazırlayan kaynaklardan biridir. Çağlar boyunca Lilith mitini kendi lehine olacak şekilde yöneten eril zihniyet, toplumsal cinsiyet normlarına uygun tutum ve davranışlar sergilemeyen kadınlara yüklenen olumsuz sıfatların taşıyıcısı olmuştur.

Ataerkil ideoloji çerçevesinde oluşan toplumsal cinsiyet, kadın ve erkek arasındaki tahakküm ilişkisinin temellerini oluşturmaktadır. Erkeğin kadın üzerinde güç kurma isteğini yansıtan toplumsal cinsiyet rolleri yüzyıllar boyunca çeşitli formlarda sunulmuş ve içselleştirilmiştir. Toplumsal cinsiyete dayalı bir yapı üzerinde kurgulanan düzende kadın, erkeğin aşağısında ve korunmaya muhtaç olarak konumlandırılmıştır. Eril toplum yapısı içinde saf, edilgen, söz dinleyen kadınlar ideal kadın -Havvaolarak görülmektedir. Kadına yüklenen roller çerçevesinde ağırbaşlılık ve boyun eğme gibi özellikler olumlu anlamlar taşırken kadının cinselliği, hazzı kötülükle ya da günahla bağdaştırılmaktadır. Bir kadının erkekle aynı değerde olması, bireyselliği ve aktif olarak haz alma isteği ataerkil düzende kabul

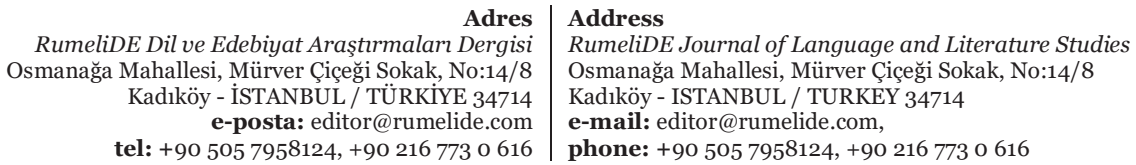


görmemektedir. Lilith, eril gücün kadına yüklediği anlamların ötesinde kendi gücünün ve cinselliğinin farkında olan bir kadın figürüdür. Her şeye rağmen özünden ve bağımsızlığından ödün vermemiştir. İdeal kadın tanımına uymayan Lilith'in kontrol edilemez yapısı eril güç için korku unsuruna dönüşmüştür. Böylesi kadınların kötü olduğu ve toplum tarafından dışlanacağına yönelik kolektif bilinçdışı normlar geliştirilmiştir. Eril olanın kadına ve cinselliğe dair yaşadığı korku kadın üzerinde hâkimiyet kurma çabasının temelinde yer almaktadır. Adem'in Lilith üzerinde kurmaya çalıştı̆̆ı otorite ataerkil toplum düzeni içinde erkeğin kadın üzerindeki tahakkümünün Tanrısal dünyayla kurulan bağdaki yansımasıdır. Lilith, Eril Tanrı'ya zıt ama onunla eş değerde bir figürdür.

Lilith mitolojiden ilhamını alan, intikamcı ve kötülük getiren kadın anlamına gelen femme fatale özelliklere sahip kadın, erkeğin boyunduruğu altına girmek istemeyip cesur yapısıyla özgürlüğü için savaşan ilk kadın olarak iki zit kimliğe bürünmüştür. Lilith, ataerkil düzene başkaldıran bir figür olarak düşünülse de varoluşun ve eşitliğin arayışı içindedir. Bir bütünün iki eş parçası olan kadın ve erkeğin yaratılıştan bu yana yaptığı ritüel kavgalar ve otorite savaşları bireyleri insan olmanın bilincinden uzaklaştırmaktadır. Kadının ne Lilith gibi bir kahraman ne de Havva gibi boyun eğen bir yapıya bürünmeden, insan olmanın değeriyle erkeklerle eşit şartlarda ve eşit haklara sahip bir yaşam sürmelidir.

\section{Kaynakça}

Akdeniz, D. (2017). Eski Ahit’te Yemeğin Resim Sanatına Yansıması. Social Sciences Studies Journal, 3 (6), 701-713.

Akça, T. E. ve Tönel, E. (2011). Erkek(lik) Çahş̧alarma Teorik Bir Çerçeve: Feminist Çalışmalardan Hegemonik Erkekliğe. Medyada Hegemonik Erkek(lik) ve Temsil, İstanbul: Kalkedon Yayınları, (Editör: İlker ERDOĞAN), 11-39.

Akmaz, G. (2019). Mitoloji ve Cinsiyet: Hint ve Yunan Mitolojilerinde Ataerkil Dönüşüm. Yayımlanmamıs Doktora Tezi. Ankara Üniversitesi.

Akyldız E., C. (2013). Mitolojide Çocuk Katili Kadınlar Lilith Lamia Medea. Zeitschrift Für Die Welt Der Türken, 5(1), 89-103.

Ali, Z. (2014). İslami Femizimler. (Çev. Öykü Elitez). İstanbul: İletişim Yayıncllı.

Altunay, E. (2014). Paganizm-I. İstanbul: Hermes Yayınları.

Armstrong, K. (2005). Mitlerin Kısa Tarihi. (Çev. Dilek Şendil) İstanbul: Merkez Yayıncılık.

Atay, T. (2004). Erkeklik En Çok Erkeği Ezer!. Toplum ve Bilim, 101: 15-46.

Basmacı, P. (2021). Feminizm Bağlamında Lilith Efsanesi ve '9 Kere Leyla Filmi'. Ordu Üniversitesi Sosyal Bilimler Araştırmaları Dergisi, 11 (3), 965-98o. Doi: 10.48146/odusobiad.969266.

Bayat, F. (2012). Türk mitolojik sistemi (ontolojik ve epistemolojik bağlamda Türk mitolojisi). II. Cilt, 2. Baskı, İstanbul: Ötüken Yayınları.

Beğenç, C. (1974). Anadolu Mitolojisi. İstanbul: Milli Eğitim Basımevi.

Berktay, F. (2000). Tektanrılı Dinler Karşısında Kadın. İstanbul: Metis Yayınları.

Berktay, F. (2010). Türkiye'de Toplumsal Cinsiyet Çalışmaları Eşitsizlikler, Mücadeleler, Kazanımlar, (Kadınlar ve Erkekler:Kimlik ve Temsil). İstanbul: Koç Üniversitesi Yayınları.

Boratav, P., N. (2012). Türk Mitolojisi. (Çev. Recep Özbay). Ankara: Bilgesu Yayıncılık.

Campbell, J. (1995). İlkel Mitoloji/Tanrının Maskeleri. (Çev. K. Emiroğlu) Ankara: İmge Yayıncılık.

Chatzoudos M., Ç. (2018). Kiki Smith’in Çalışmalarında Mitolojik Unsurlar. İdil Dergisi, S.7, C. 49, 1081-1087.

Çaha, Ö. (2010). Sivil Kadın: Türkiye’de Kadın ve Sivil Toplum. Ankara: Savaş Yayınları.

$$
\begin{array}{r|l}
\text { Adres } & \begin{array}{l}
\text { Address } \\
\text { RumeliDE Dil ve Edebiyat Araştırmaları Dergisi }
\end{array} \\
\text { RumeliDE Journal of Language and Literature Studies } \\
\text { Osmanağa Mahallesi, Mürver Çiçeği Sokak, No:14/8 } & \text { Osmanağa Mahallesi, Mürver Çiçeği Sokak, No:14/8 } \\
\text { Kadıköy - İSTANBUL / TÜRKIYE 34714 } & \text { Kadıköy - ISTANBUL / TURKEY 34714 } \\
\text { e-posta: editor@rumelide.com } & \text { e-mail: editor@rumelide.com, } \\
\text { phone: +90 505 7958124, +90 } 216773 \text { o } 616
\end{array}
$$


Çınar, A. (2018). Lilith Yahudi Mitolojisinde Ana Tanrıça'nın Düşüş ve Şeytana Dönüşüm Serüveni. Bilimname: Düşünce Platformu, 35 (1), 363-395.

Çı̆̆, M., İ (2015). Gilgameş 'Tarihte İlk Kral Kahraman'. İstanbul: Kaynak Yayınları.

Çı̆̆, M., İ. (2005). Bereket Kültü ve Mabet Fahişeliği. İstanbul: Kaynak Yayınları.

Donovan, J. (2014). Feminist Teori (Çev. A. Bora ve M. A ̆̆duk Gevrek ve F. Sayılan) İstanbul: İletişim Yayınları.

Depe, D. (2010). Ayfer Tunç un Kapak Kızı Romanında Toplumsal Cinsiyet Rolleri. Presented at the III. Uluslararası Türk Dili ve Edebiyatı Öğrenci Kongresi. 465-475.

Drury, N. (1989). Şamanizm ‘Şamanlığın Ögeler’. (Çev. Erkan Şimşek). İstanbul: Okyanus Yayıncılık.

Eliade, M. (1990). Dinin Anlamı Ve Sosyal Fonksiyonu. (Çev. M. Aydın) Ankara: Kültür Bakanlı̆̆ı.

Erhat, A. (2018). Mitoloji Sözlüğü. İstanbul: Remzi Kitabevi.

Estin, C. ve Laporte, H. (2002). Yunan ve Roma Mitolojisi. (Çev. Musa Eran), Ankara: Tübitak Popüler Bilim Kitapları.

Fedai, Ö. (2012). Tanzimat Romanında Lilith’in Ruh İkizi Bir Femme Fatale Olarak Zehra. Yeni Türk Edebiyatı Araştırmaları, (7), 79-93.

Gazanfergizi, A. (2019). Köpek Kadın'dan Lilit, Alkarısı Ve Isıkıl-Lilla’ya Kadar Uzanan Mitolojik Hat. Uluslararası Halkbilimi Araştırmaları Dergisi, c. 2, s. 3, 125-134.

Gözen, Ö. ve Adigüzel, İ., B. (2017). Toplumsal Cinsiyetin İnşasında Yunan Mitolojisi: Kadın- Erkek Ve Aile Kavramlarına Genel Bir Bakış. Current Debates in Labour Economics, Demography \& Gender Studies: Volume 7.181-195. http://ijopec.co.uk/wp-content/uploads/2018/o1/V7.pdf

Gilbert, S. ve Gubar, M-S. (2016). (Madwoman in the Attic) Tavanarasındaki Deli Kadın. (çev: Nil Sakman). İstanbul: Aylak Adam Yayınları.

Gezgin, D. (2007). Bitki Mitosları. İstanbul: Sel Yayıncılık.

Gültepe, N. (2017). Türk Kadın Tarihine Giriş. İstanbul: Ötüken Yayınları.

Hooke, S. H. (1993). Ortadoğu Mitolojisi. ( Çev. Alâeddin Şenel). Ankara: İmge Kitabevi.

Işık, S. Y. (2018). Yılan, Su, Söz: Kadın Düşmanlığı İle Belirsizlik Korkusu Arasındaki İlişkiye Dair Bir Yorum Denemesi. Folklor/Edebiyat, 24(93), 177-196.

Jung, C. G. (2013). Dört arketip. (Çev: Z. A. Yılmazer) 4. Baskı, İstanbul: Metis Yayıncılık.

Karaca, Ş. (2019). My Red Hair Is My Freedom: Image Of Lilıth In Orhan Pamuk's Novel, The Red Haired Woman. TÜBAR XLV, 119-134.

Kef, E. (2018). Cinsiyet Algısının Mitsel Kökeni. Bursa Uludă̆ Üniversitesi Fen-Edebiyat Fakültesi Felsefe Dergisi 'Kaygi', 22-41.

Kılıç, Y. ve Eser, E. (2018). Lohusalık Sendromu (Al Ana/Alkarısı/Albastı)’Nun Eskiçağ Yakındoğu Toplumlarının Kültürlerindeki İzleri: Lilith Gerçeği. Akademik Tarih Ve Düşünce Dergisi, 5 (17 Ek), 29-60.

Kitab-ı Mukaddes, Tekvin (Yaratılış).

Kocabaş A., D. (2013). Antik Yunan'da Toplumsal Cinsiyet Rollerinin Temsili. Yedi: Sanat Tasartm ve Bilim Dergisi, s. 10, 15-27.

Kramer, S., N. (1999). Sümer Mitolojisi. (Çev. Hamide Koyukan) İstanbul: Kabalcı Yayınları.

Kurt, M. (2010). Tanrıça Kültü Ve Hıristiyanlık’taki Meryem Figürüne Etkileri. Yayımlanmamış Yüksek Lisans Tezi. Rize Üniversitesi Sosyal Bilimler Enstitüsü Felsefe Ve Din Bilimleri Ana Bilim Dalı Dinler Tarihi Bilim Dalı, Rize.

Nar, M., Ş. (2014). Günümüz Toplumunda Mitler Anadolu Halk Efsaneleri Üzerine Genel Bir Değerlendirme. Folklor / Edebiyat Dergisi, 55-77.

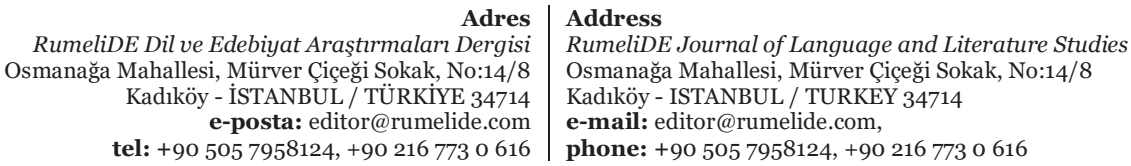


524 / RumeliDE Journal of Language and Literature Studies 2022.26 (February)

A feminist perspective on perception of women in mythology and religions through the figure of 'Lilith' / / S. C. Yeter; K. Özcan (pp. 506-525)

Oylubaş, D. (2013). Türk Edebiyatında Lilith: 2000 Sonrası Türk Romanında Havva'dan Önceki Kadın. I. Genç Akademisyenler Sempozyumu, Bildiriler 6-7 Kasım 2013, Epa-Mat, Ankara, 433-449.

Özbay, E. (2013). Adem-Havva-Lilith Figürleri İzleğinde Bir Olanaksızlık Miti: Aşk. İdil Dergisi, s.10, c.2, 40-58.

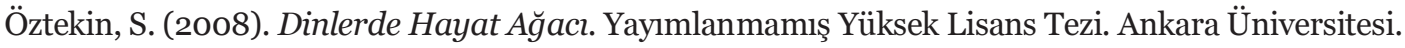

Öztürk, M. (2004). Âdem, Cennet ve Düşüş. Milel ve Nihal, 1 (2), 151-186.

Palabıyık, M., H. (2019). Toplumsal Cinsiyet ve İslam Düşüncesinde Kadın. Atatürk Üniversitesi Kadın Araştırmaları Dergisi-ATAKAD, 1(2), 81-99.

Palabıyık, H. (2020). Toplumsal Cinsiyet ve İslam Düşüncesinde Kadın. Erişim Tarihi: 24.12.2021.https://millivicdan.org/makale-toplumsal-cinsiyet-ve-\%C3\%84\%C2\%Boslamdusuncesinde-kadin--714.html

Patai, R. (1964). Lilith. The Journal of American Folklore, 77(306), 295. doi:10.2307/537379.

Ramazanoğlu (1944). Gılgamış Destanı. İstanbul: Cumhuriyet Kitapları.

Schimmel, A. (2004). Tanrının Yeryüzündeki İşaretleri. İstanbul: Kabalcı Yayınevi.

Seyidoğlu, B. (2017). Mitoloji Üzerine Araştırmalar 'Metinler ve Tahliller'. İstanbul: Dergâh Yayınları.

Sivri, M. ve Akbaba, C. (2018). Dünya Mitlerinde Yılan. Folklor/Edebiyat, 24(96), 53-64. Do1: 10.22559

Stone, M. (2000). Tanrılar Kadınken. ( Çev. Nilgün Peyman). İstanbul: Payel Yayınevi.

Şahin, K. ve Toprak, S. (2016). Kültürel ve Dinsel Perspektifte Kadın Kimliği. Turkısh Studıes, 11(18), 203-214. DOI Number: http://dx.doi.org/10.7827/TurkishStudies.9817.

Şahin, E. (2013). Batı'da ve Türkiye'de Kadın Hareketleri ve Feminizm. Ankara: Ürün Yayıları.

Tokyürek, H. (2016). Eski Uygur Budist Metinlerinde Şeytan, Yılan, Kadın İlişkisi. Türkiyat Mecmuası, 26(1), 301-310.

Tuğrul, S. (2010). Ebedi Kutsal Ezeli Kurban 'Çok Tanrılıktan Tek Tanrılı̆̆a Kutsal ve Kurbalık Mekanizmaları. İstanbul: İletişim Yayınları.

Uraz, M. (1994). Türk Mitolojisi. İstanbul: Düşünen Adam Yayınları.

Ünal, A. (2017). Yahudi Geleneğinde Kadının Yaratılışı ve Lilit Efsanesi. Çukurova Üniversitesi İlahiyat Fakültesi Dergisi, 17 (2), 103-115.

Vural, A., Ebru (2020). Güngör Dilmen’in Bağdat Hatun Oyununda Demonik Kadın Kurgusu. Akademik Dil ve Edebiyat Dergisi, 4 (4), s. 1001-1019. DOI: 10.34083/akaded.807175.

Yeniçeri, Z. ve Korkmaz, L. ve Kökdemir, D. (2015). An Existential Alliance Of Byronic And 'Lilithian' Heros. Metu Gwc Conferance, 1035-1043.

Yeniçeri, Z. (2015). İş Yaşamında Cinsiyetçiliğin Kökenleri:Lilith, Lucy ve Ardi. Türk Tabipleri Birliği Mesleki, Sağlık ve Güvenlik Dergisi, 13-18.

Yılmaz, K. ve Gezer, H. (2018). Fuzûlî’nin Leylâ ve Mecnûn'unun Kaynakları: Lilith’ten Leylâ'ya. Süleyman Demirel Üniversitesi Fen-Edebiyat Fakültesi Sosyal Bilimler Dergisi, S.43, 1-15.

Yonar, G. (2019). Toplumsal Değerler Etrafında Kadınlar, Mitler ve Toplumsal Cinsiyet Aranjmanları. Erişim tarihi: 9.12.2021. https://bilmekvaktidir.com/author/gonul-yonar/

Zıngsem, V. (2007). Lilith. ( Çev. D. D. Yüzer). İzmir: İlya Yayınları.

URL, 1 Adem’in İlk Eşi Olduğuna İnanılan İlk Feminist Lilith Ve İbrani İftiraları. Erişim tarihi: 28.12.2021. https://kokler-ve-kanatlar.webnode.fr/products/adem\%27in-ilk-e\%c5\%9fioldu\%c4\% funa-inan\%c4\%b1lan-ilk-feminist-lilith-efsanesi-ve-ibrani-iftiralar\%c4\%b1/?utm_source=copy\&utm_medium $=$ paste\&utm_campaign $=$ copypaste\&utm_content=http\%3A \%2F\%2Fkokler-ve-kanatlar.webnode.fr\%2Fproducts\%2Fadem\%2527in-ilk-e\%25c5\%259fi-

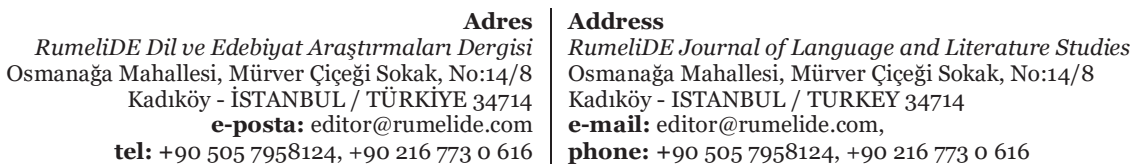


oldu\%25c4\%259funa-inan\%25c4\%25b1lan-ilk-feminist-lilith-efsanesi-ve-ibraniiftiralar\%25c4\%25b1-\%2F

\section{EK 1}

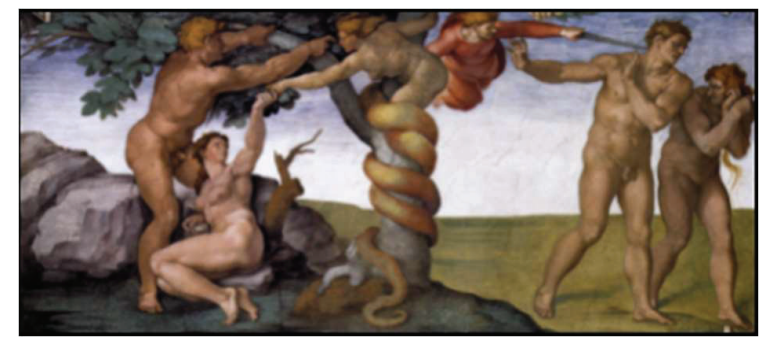

Michelangelo’nun 1510 yılında yapmış olduğu ‘ílk Günah ve Cennetten Kovuluş’ adlı fresk çalışması. https://tr.wikipedia.org/wiki/\%C4\%Bolk_G\%C3\%BCnah_ve Cennetten_Kovulu\%C5\%9F\#/media/Dosya:Michelangelo, Fall and Expulsion from Garden of Eden 00.jpg

EK 2

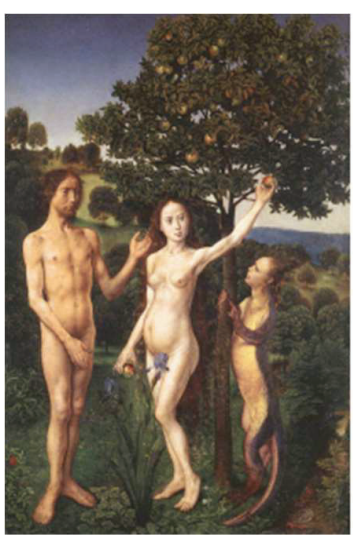

Hugo van der Goes’in 'Düşüş’ resmi.
EK 3

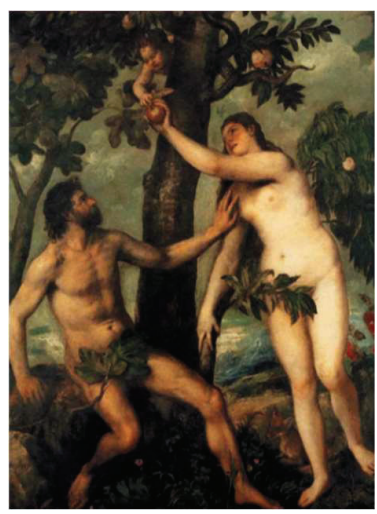

ve

Tiziano Vecellio, 'Adem ile Havva'

https://arkeopolis.com/hiristiyan-ikonografyasinda-yaratilis-bastan-cikarilis-ve-cennetten-kovulussahnelerinde-gorulen-kozmolojik-anlamlar/

\section{EK 4}
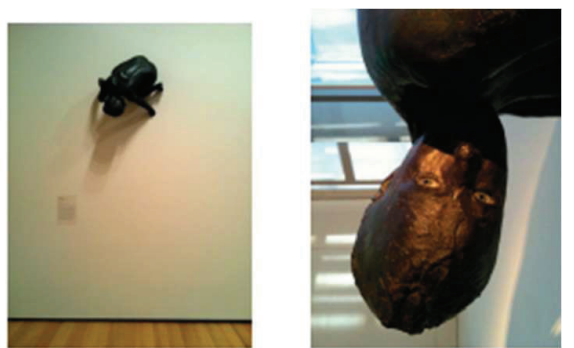

Kiki Smith (1994) ‘Lilith’ adlı heykeli

https://www.metmuseum.org/art/collection/search/486711

RumeliDE Dil ve Edebiyat Araştırmalar Dergisi Osmanağa Mahallesi, Mürver Çiçeği Sokak, No:14/8 Kadıköy - İSTANBUL / TÜRKIYE 34714 e-posta: editor@rumelide.com tel: +90 $5057958124,+902167730616$
Address

RumeliDE Journal of Language and Literature Studies

Osmanağa Mahallesi, Mürver Çiçeği Sokak, No:14/8

Kadıköy - ISTANBUL / TURKEY 34714

e-mail: editor@rumelide.com,

phone: +90 $5057958124,+902167730616$ 